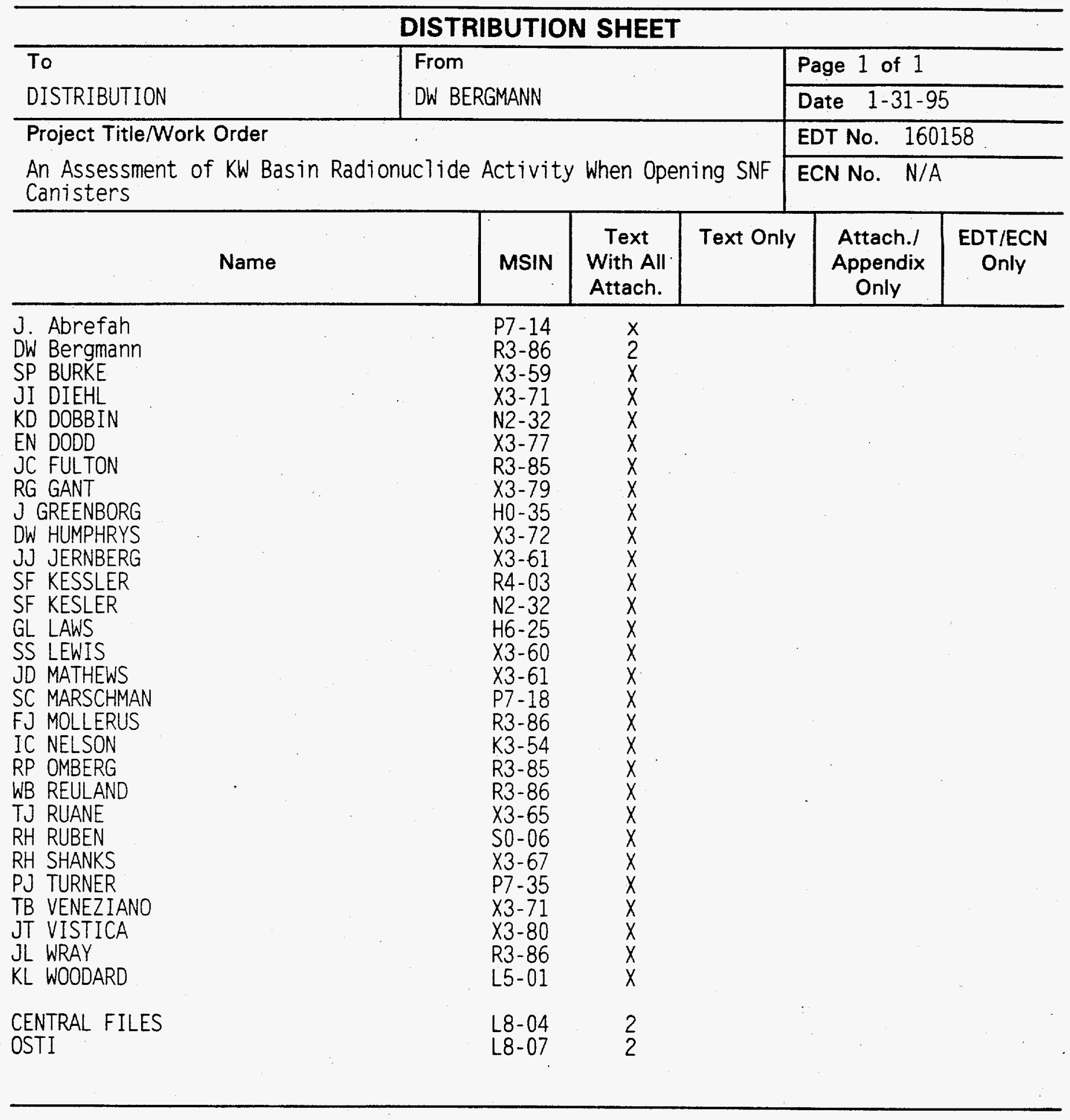




\section{DISCLAIMER}

Portions of this document may be illegible in electronic image products. Images are produced from the best available original document. 


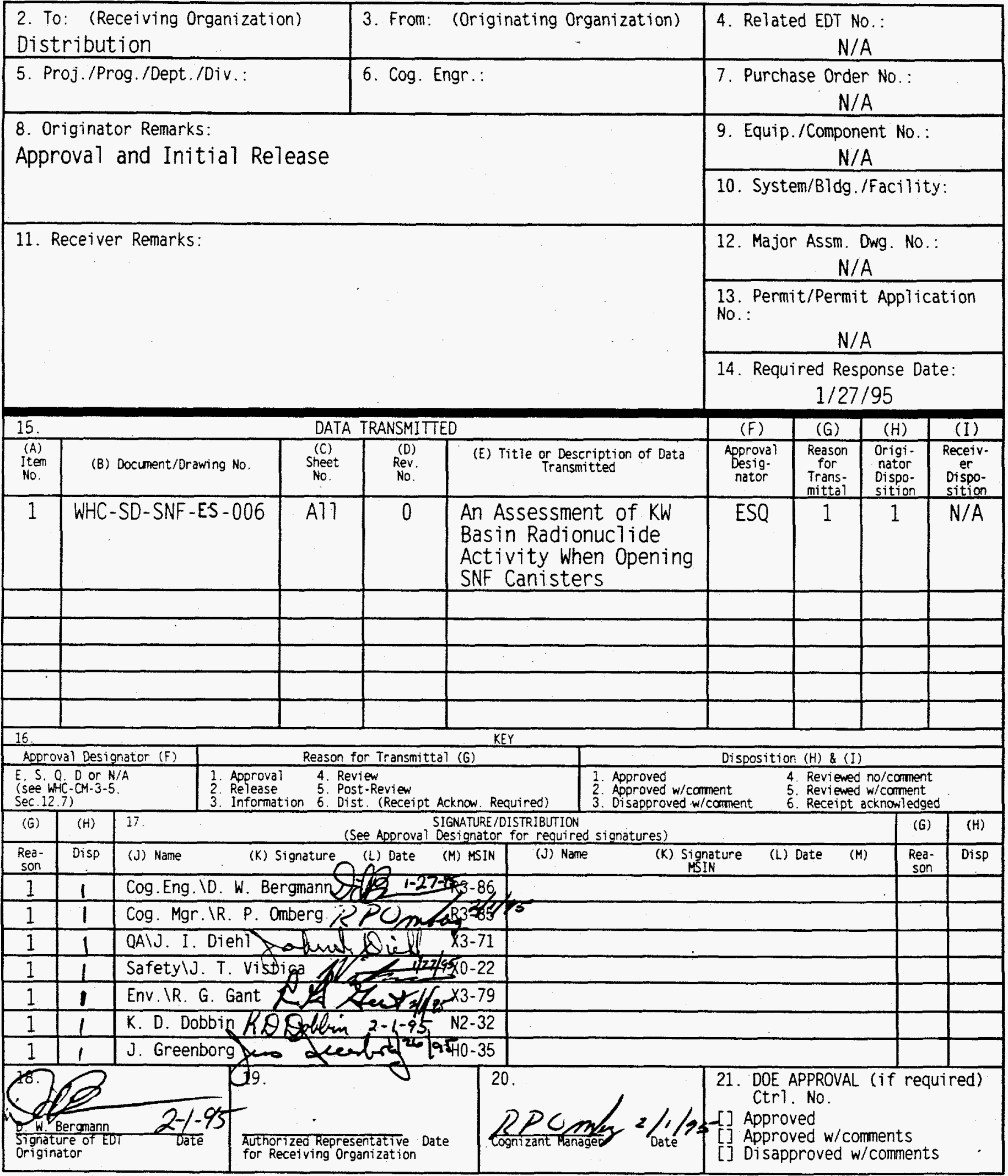

BD-7400-172-2 (04/94) GEF097 


\section{RELEASE AUTHORIZATION}

Document Number: WHC-SD-SNF-ES-006, REV 0

Document Title: An Assessment of KW Basin Radionuclide Activity When Opening SNF Canisters

Release Date: $\quad 2 / 3 / 95$

This document was reviewed following the procedures described in WHC-CM-3-4 and is:

APPROVED FOR PUBLIC RELEASE

WHC Information Release Administration Specialist:

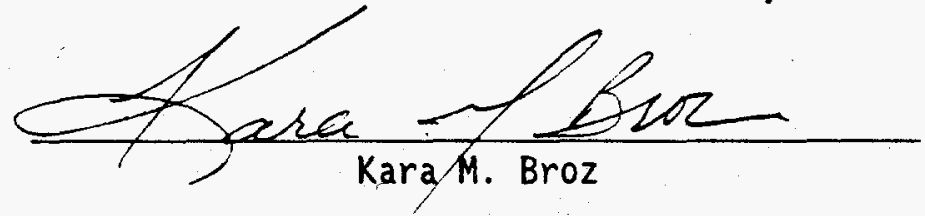

February 3, 1995

TRADEMARK DISCLAIMER. Reference herein to any specific commercial product, process, or service by trade name, trademark, manufacturer, or otherwise, does not necessarily constitute or imply its endorsement, recomendation, or favoring by the United States Government or any agency thereof or its contractors or subcontractors.

This report has been reproduced from the best available copy. Available in paper copy and microfiche. Printed in the United States of America. Available to the U.S. Department of Energy and its contractors from:

U.S. Department of Energy

office of Scientific and Technical Information (OSTI)

P.0. Box 62

Oak Ridge, TN 37831

Telephone: (615) 576-8401

Available to the public from:

U.S. Department of Cormerce

National Technical Information Service (NTIS)

5285 Port Roysl Rood

Springfield, VA 22161

Telephone: (703) $487-4650$ 


\section{SUPPORTING DOCUMENT}

1. Total Pages

\begin{tabular}{l|l|c|}
$\begin{array}{l}\text { 2. Title } \\
\text { An Assessment of KW Basin Radionuclide Activity } \\
\text { When Opening SNF Canisters }\end{array}$ & $\begin{array}{l}\text { 3. Number } \\
\text { WHC-SD-SNF-ES-006 }\end{array}$ & $\begin{array}{c}\text { Rev No. } \\
\text { 5. Key words }\end{array}$ \\
$\begin{array}{l}\text { Fuel Characterization, 105KE/KW Basins, fuel } \\
\text { canister, radionuclide releases, fuel sampling }\end{array}$ & $\begin{array}{l}\text { S. Author } \\
\text { Stgnature } \\
\text { Organization/Charge Code 2C000/22601 }\end{array}$ \\
\hline
\end{tabular}

7. Abstract

This report estimates the amount of radionuclides that can be released from Mark II spent nuclear fuel (SNF) canisters in KW Basin when canisters are opened for SNF fuel sampling as part of the SNF Characterization Program. The report also assesses the dose consequences of the releases and steps that can be taken to reduce the impacts of these releases. BY WHIC

DATE FEB 061995 sta 4 


\title{
AN ASSESSMENT OF KW BASIN RADIONUCLIDE ACTIVITY WHEN OPENING SNF CANISTERS Revision 0
}

January 1995

\author{
Prepared for \\ WESTINGHOUSE HANFORD COMPANY \\ P.O. Box 1970 \\ Richland, Washington 99352
}

\author{
Prepared by \\ MOLLERUS ENGINEERING CORPORATION \\ 455 Los Gatos Blvd., Suite 205 \\ Los Gatos, California 95032
}

\section{DISCLAIMER}

This report was prepared as an account of work sponsored by an agency of the United States Government. Neither the United States Government nor any agency thereof, nor any of their employees, makes any warranty, express or implied, or assumes any legal liability or responsibility for the accuracy, completeness, or usefulness of any information, apparatus, product, or process disclosed, or represents that its use would not infringe privately owned rights. Reference herein to any specific commercial product, process, or service by trade name, trademark, manufacturer, or otherwise does not necessarily constitute or imply its endorsement, recommendation, or favoring by the United States Government or any agency thereof. The views and opinions of authors expressed herein do not necessarily state or reflect those of the United States Government or any agency thereof. 


\title{
MOLLERUS ENGINEERING CORPORATION
}

\author{
AN ASSESSMENT OF \\ KW BASIN RADIONUCLIDE ACTIVITY \\ WHEN OPENING SNF CANISTERS \\ Revision 0
}

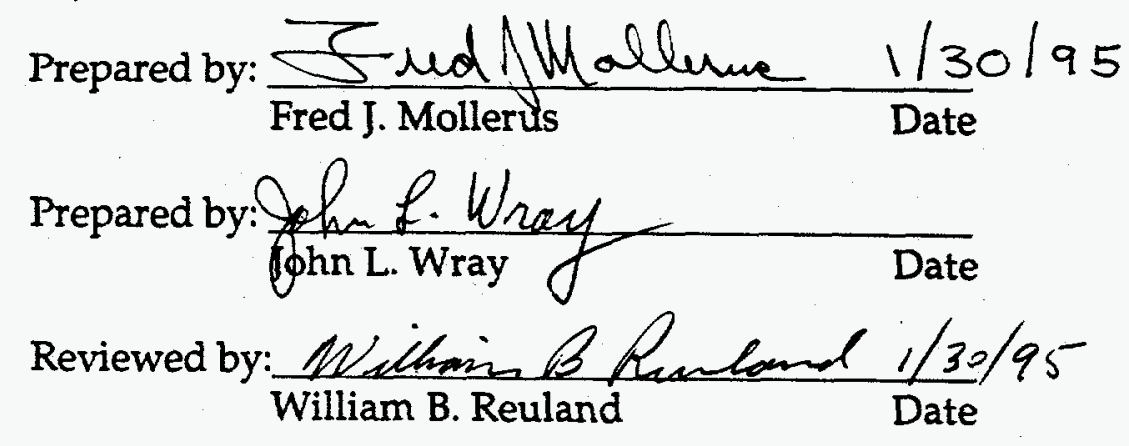




\section{ACKNOWLEDGMENTS}

In appreciation for their contribution, the author thanks the following for reviewing and providing information and constructive comments and guidance during preparation of this report.

D. Bergmann, Westinghouse Hanford Company

S. P. Burke, Westinghouse Hanford Company

R.G. Gant, Westinghouse Hanford Company

K.R. Conn, Westinghouse Hanford Company 


\section{TABLE OF CONTENTS}

1.0 Introduction

2.0 Summary $\quad 2$

$\begin{array}{lll}3.0 & \text { Discussion } & 8\end{array}$

3.1 Background 8

3.2 Fission Product Inventory 8

3.3 Estimated Releases 9

$3.4 \quad$ Analysis of Releases $\quad 10$

3.4.1 Loadout Pit Water Cs 137 Activity 11

3.4.2 Main Basin Water Cs 137 Activity $\quad 12$

$\begin{array}{lll}\text { 3.4.3 Airborne Activity } & 14\end{array}$

3.4.4 Transuranic (TRU) Activity 15

3.4.5 Ion Exchanger Module Considerations 16

$\begin{array}{ll}3.5 & \text { Mitigation } \\ \end{array}$

3.5.1 Canister Gas Bleedoff and Sampling 19

3.5.2 DXM Flow Path 20

4.0 References 21

Appendix A: $\quad$ Estimated Fission Product Releases from Spent Fuel Appendix B: $\quad$ Canister Characteristics and Impact on Gas and Liquid Sampling

Appendix C: $\quad$ Estimated Dose Rate Above a Water Pool from Cs 137 in the Pool 


\subsection{INTRODUCTION}

\section{BACKGROUND}

N Reactor spent fuel is being stored in sealed canisters in the KW Basin. Some of the canisters contain damaged fuel elements. There is the potential for release of Cs 137, $\mathrm{Kr} 85, \mathrm{H} 3$, and other fission products and transuranics (TRUs) when canisters are opened. Canister opening is required to select and transfer fuel elements to the 300 Area for examination as part of the Spent Nuclear Fuel (SNF) Characterization program. This report is an analysis of the potential to increase KW Basin water and airborne activity when canisters containing broken fuel are opened. The report also covers measures to mitigate potential activity increases.

\section{OBJECTIVE}

The objectives of this report are to provide the following:

- An analysis of the potential to increase KW Basin water and airborne activity due to opening of barrels containing broken fuel.

- Recommendations for measures to mitigate potential activity increases. 


\subsection{SUMMARY}

2.1 The results described in this report and summarized below are based on statistical analysis of 1983 mark I canister sipping and straight line extrapolation to 1995. This could be non-conservative. There is capacity in KW Basin to accommodate larger activity releases than those based on the 1983 data. Until there is actual 1995 fuel sampling experience and statistics, the following minimum precautions should be taken:

- Take liquid and gas samples before decapping barrels.

- Vent barrels before decapping.

- Supplement ventilation where venting of barrels is to occur.

- Start decapping with one new active IXM in reserve ready to be valved into operation.

2.2 Based on the 1983 data, there is a $98 \%$ probability $^{1}$ that the release of Cs 137 from a canister barrel when it is opened to sample fuel will be less than 3.71 $\mathrm{Ci}$. The expected release is $0.696 \mathrm{Ci}$. There are other isotopes, such as $\mathrm{Sr} 90$, that will also be released. However, Cs 137 is the dominant water soluble isotope and is used in this report to characterize basin water radionuclide activity changes during fuel sampling. Derivation of the probability estimate is discussed in Appendix A.

2.3 Canisters will be opened in the KW transfer channel of the south loadout pit. The maximum concentration of isotopes will occur in this pit; some of the radionuclides will spread into the main basin. Peak Cs 137 activity increases associated with opening a canister barrel that releases $3.71 \mathrm{Ci}$ of Cs 137 into the loadout pit are estimated to be:

In the loadout pit

In the main basin
$82 \mu \mathrm{Ci} / \mathrm{L}$

$$
0.01 \mu \mathrm{Ci} / \mathrm{L} \text {, }
$$

\footnotetext{
${ }^{1}$ The $98 \%$ probability release is that quantity of activity that should not be exceeded in 98 out of 100 decapped canister barrels, while the expected release is the average or mean release per barrel if a large number of barrels are decapped.
} 
These estimates are based on an initial Cs 137 activity level of $0.05 \mu \mathrm{Ci} / \mathrm{L}$ in the main basin and an Ion Exchanger Module (IXM) ion removal efficiency of $99 \%$. The increase will be higher or lower than these estimates in proportion to the amount that the Cs 137 release from the canister barrel is higher or lower than $3.71 \mathrm{Ci}$. It is also somewhat proportional to the frequency of barrel decapping. Since the expected release of Cs 137 from a canister barrel is less than $3.71 \mathrm{Ci}$, the expected pit and basin activity increases are less than shown above.

It is estimated that radiation exposure will increase by $5 \mathrm{mr} / \mathrm{hr}$ for each $100 \mu \mathrm{Ci} / \mathrm{L}$ of $\mathrm{Cs} 137$ in the loadout pit area.

2.4 In the past, the Cs 137 activity level in the KW Basin has varied widely from a high of $1 \mu \mathrm{Ci} / \mathrm{L}$ in 1993 to a present day low of $0.05 \mu \mathrm{Ci} / \mathrm{L}$. A suggested allowable limit during fuel sampling is $0.5 \mu \mathrm{Ci} / \mathrm{L}$. This is 10 times the low and half the 1993 high value.

2.5 The times needed to remove $90 \%$ of the Cs 137 with high efficiency ion exchanger modules (IXMs) at 150 GPM flow are:

$$
\begin{array}{ll}
\text { Loadout pit } & 3 \text { hours } \\
\text { Main basin } & 11 \text { days }
\end{array}
$$

This means that several canister barrels per shift can be opened in the loadout pit. Increases in main basin activity will be cumulative if more than one canister barrel is opened in any 11 day period. However, a comparison of the suggested allowable basin limit discussed in Section 2.3 and the estimated incremental increase in main basin activity discussed in Section 2.2 indicates that as many as 40 canister barrels could be opened in any 10 day period.

2.6 Figures 2-1 and 2-2 show the KW Basin Cs 137 activity for two conditions:

- Figure 2-1 shows KW Basin Cs 137 activity if two canister barrels are decapped and it is assumed that there is a release of $3.71 \mathrm{Ci}$ of Cs 137 into the pit each time a canister barrel is decapped.

- Figure 2-2 shows KW Basin Cs 137 activity if a series of canister barrels are opened. It assumes that four barrels are opened each day, two at a time, in 3 hour intervals, and that each canister barrel releases the 
expected amount of $\mathrm{Cs} 137,0.696 \mathrm{Ci}$, into the pit. The main basin activity increase will not be significant. In fact, the main basin will remain below the suggested allowable limit even if all these canister barrels release the $98 \%$ probability value of $3.71 \mathrm{Ci}$.

2.7 The results shown are based on the following conditions:

- Vent and sampling activities are confined to the weasel pit or loadout pit.

- All decapping activities are confined to the loadout pit.

- The Ion Exchanger Modules (IXMs) are aligned so that all flow is from the loadout pit, through the DXM, and return is to the main basin. ${ }^{2}$ The IXM efficiency is $99 \%$.

- Canister opening procedures start with new IXMs in both active alignment and in standby. Sufficient water samples are taken to assure that ion exchanger efficiency is maintained at $99 \%$ or greater.

2.8 The IXM efficiency does not have to be as high as $99 \%$ to maintain main basin Cs 137 activity at $0.5 \mu \mathrm{Ci} / \mathrm{L}$, or less; a somewhat lower efficiency will suffice. However, efficiency will decrease rapidly once the IXM efficiency falls below $99 \%$ and the IXM continues to be used. For this reason, a new IXM in standby readiness is recommended. (See Section 3.4 .5 for further discussion of DXM efficiency.)

2.9 There is the potential for release of $\mathrm{Kr} 85$ and $\mathrm{H} 3$ into the $\mathrm{KW}$ Basin air space from a canister when it is opened. Even if the release occurs quickly, the $\mathrm{H3}$. activity will be less than the DOE Derived Air Concentration (DAC) limits. Although the $\mathrm{Kr} 85$ activity can momentarily be greater than its DAC, the resulting occupational exposure is a small fraction of the annual skin dose limit of $50 \mathrm{rem}$. DACs are discussed in Section 3.4.3

Airborne concentrations can be reduced by using the canister peripheral vent valve to slowly bleed off the canister gas space and to fill the canister with

\footnotetext{
${ }^{2}$ The alternate path is to return IXM outlet flow back to the loadout pit. This has several disadvantages: (1) The DXM's would not remove Cs 137 and other isotopes entering the main basin by leakage from the sealed canisters being stored in the basin. (2) There would be no flow from the main basin into the pit, making the gate separating the main basin from the loadout pit a pathway for leakage of high activity loadout pit water directly into the main basin. LXM flow paths are discussed in Section 3.5.2.
} 
basin water. This procedure should help reduce the rate of generation and release of hydrogen due to chemical reactions.

2.10 Sampling of canister gas can be done in conjunction with bleeding off canister gas discussed above by capturing canister gas bubbles as they exit the canister vent valves or by using the gas and liquid sampler. $\mathrm{Kr} 85$ activity levels in the gas sample is an indication of the total amount of KR 85 in the gas space. $\mathrm{Kr} 85$ activity could be significantly diluted if there has been hydrogen generation in the canister due to chemical reactions. For this reason, $\mathrm{Kr} 85$ concentrations are not a reliable indication of all releasable activity in a canister barrel. However, the concentration can be a measure of the $\mathrm{Kr} 85$ activity remaining in the canister barrel.

2.11 A more reliable indicator of fission product leaching will be liquid samples taken from a canister barrel before it is decapped. A Cs 137 activity on the order of $300 \mu \mathrm{Ci} / \mathrm{ml}$ of sample liquid could be an indication that fission products leached from the fuel and contained in the canister barrel water are on the order of those quantities estimated and used in this report.

2.12 Based on an allowable main basin Cs 137 limit of $0.5 \mu \mathrm{Ci} / \mathrm{L}$ and an initial main basin Cs 137 activity level of $0.05 \mu \mathrm{Ci} / \mathrm{L}$, the maximum Cs 137 activity that could be contained in a single barrel is $170 \mathrm{Ci}$, significantly greater than the $98 \%$ probability estimate of $3.71 \mathrm{Ci}$. At the same time, the loadout pit activity will increase to approximately $3750 \mu \mathrm{Ci} / \mathrm{L}$ but will reduce to less than $100 \mu \mathrm{Ci} / \mathrm{L}$ in six hours.

2.13 In the event that there is an inadvertent opening of a canister containing $3.71 \mathrm{Ci}$ of releasable Cs 137 while it is located in the main basin or the weasel pit, the average main basin activity will increase $1.0 \mu \mathrm{Ci} / \mathrm{L}$, approximately the recent historical high for the KW Basin. The IXMs will return the main basin Cs 137 activity to $0.5 \mu \mathrm{Ci} / \mathrm{L}$ in the time it takes the IXMs to process one main basin water volume, about 5 days. 


\section{KW Basin Cs 137 Activity After Opening Two Canister Barrels}

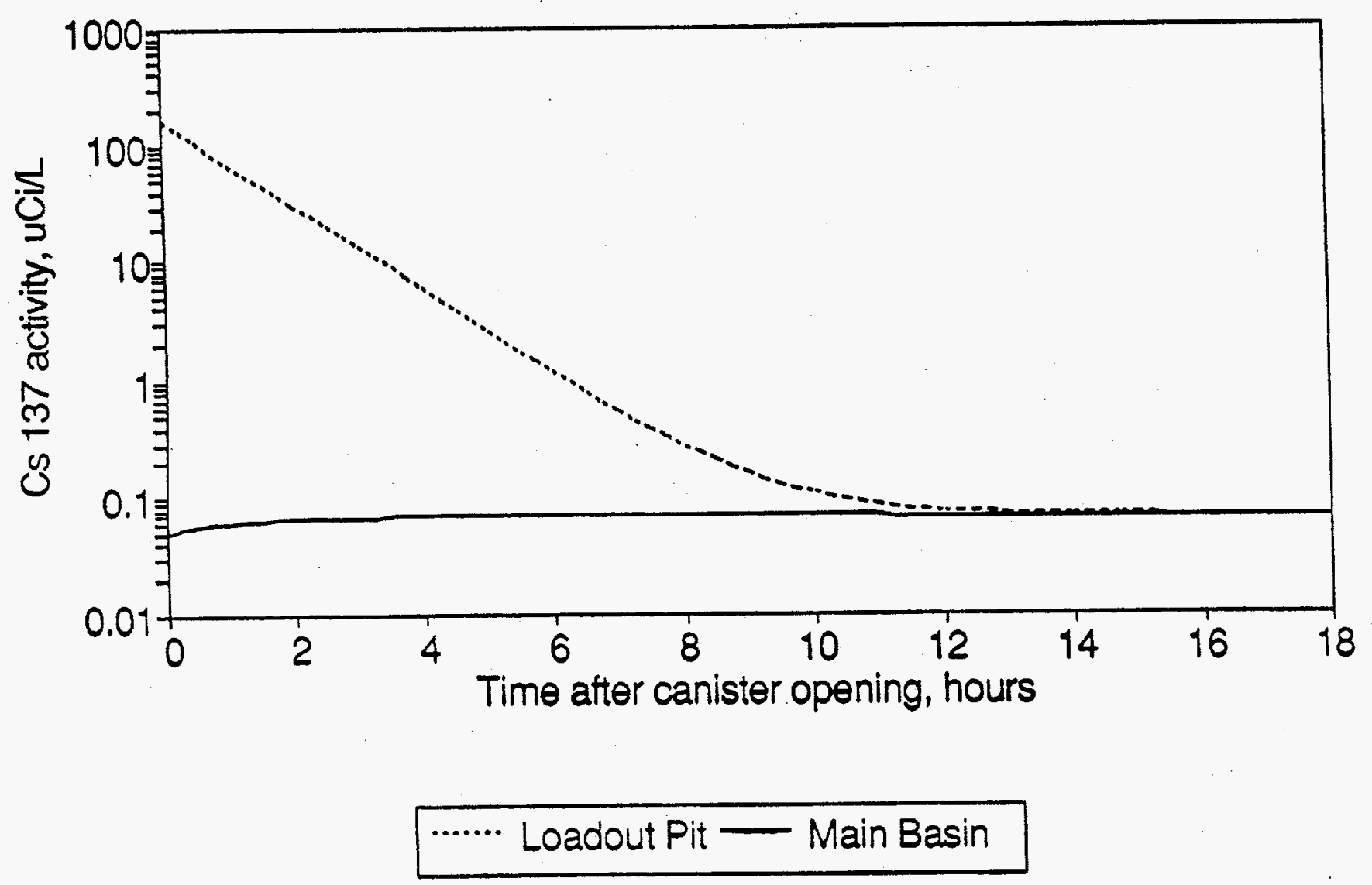

Figure 2-1 


\section{KW Basin Cs 137 Activity After Opening a Series of Barrels}

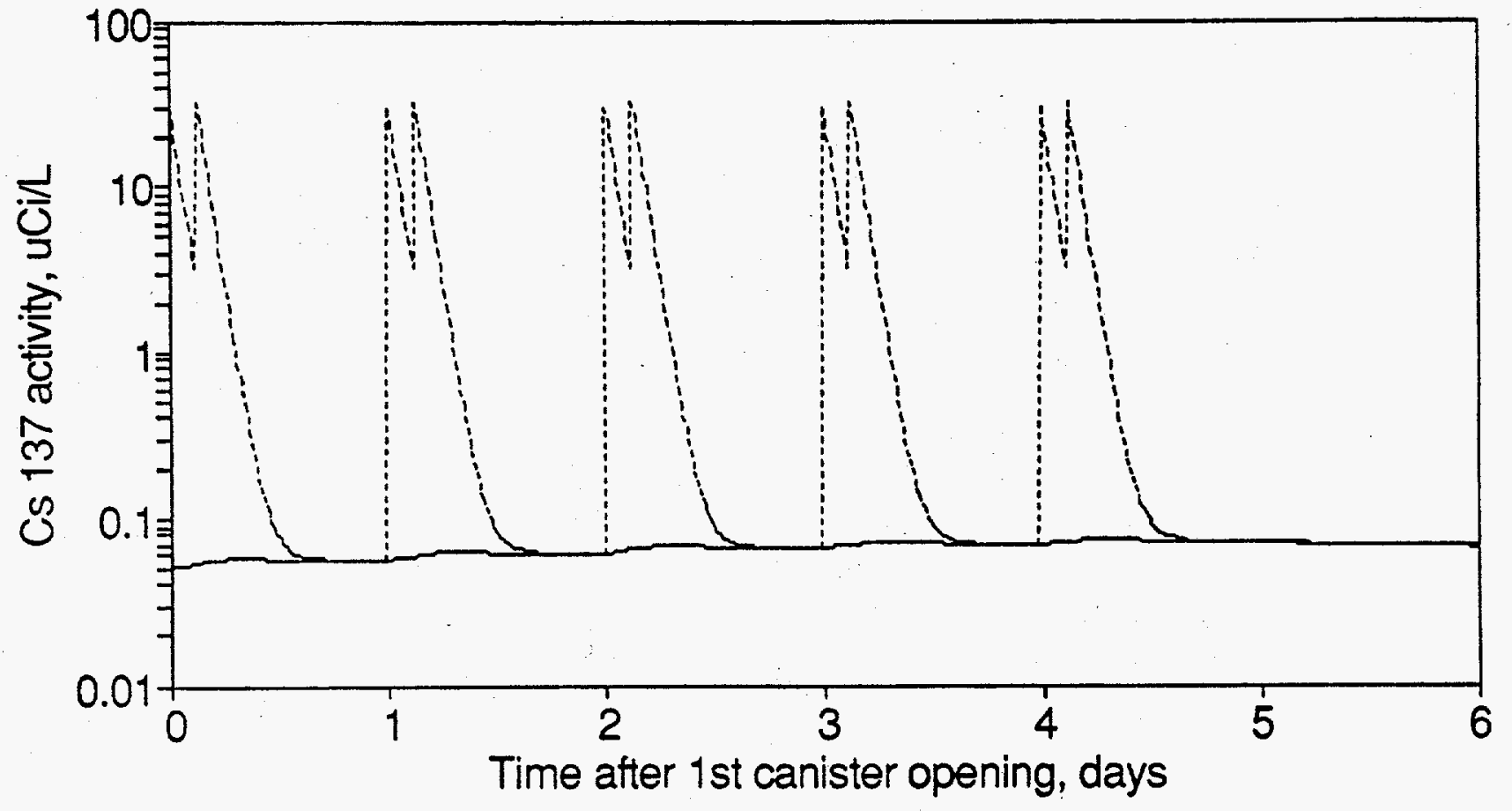

…... Loadout Pit - Main Basin

Figure 2-2 


\subsection{DISCUSSION}

\subsection{BACKGROUND}

The KW Basin contains approximately 958 tons of $\mathrm{N}$ Reactor fuel; most is stored in sealed water filled Mark II canisters, some is stored in Mark I canisters. This assessment addresses only the opening of Mark II canisters.

A canister consists of two stainless steel, closed bottom barrels attached together to be handled as a unit. Each barrel stores a maximum of seven fuel assemblies. In addition to the fuel, each barrel contains water with potassium nitrite corrosion inhibitor and a small nitrogen filled gas space. The gas space is vented to an external gas trap attached to the barrel. Gas generated in the barrel will vent to the gas trap and, in turn, to the basin water when the gas trap fills with gas and gas pressure exceeds the hydraulic head of the basin water covering the canisters.

The spent fuel stored in the canisters contains fission products, daughter isotopes, and TRUs. The more abundant are Cs 137, Sr 90, the TRUs, and the gases $\mathrm{Kr} 85$ and $\mathrm{H} 3$, some of which may be in the form of tritiated water. Some of this material may have leached into the canister water and gas space due to diffusion and corrosion of uranium and will be released into the KW Basin when canisters are opened.

\subsection{FISSION PRODUCT INVENTORY}

Table A3-1 of WHC-SD-TP-SEP-028, 'N Reactor/Single Pass Reactor Fuel Characterization Shipments Safety Evaluation for Packaging," provides a list of the worst expected activity levels for an inner and outer $\mathrm{N}$ Reactor fuel element. Since there are seven fuel assemblies (inner and outer) per sealed barrel, the inventory is seven times the listed values. The inventory of the higher activity isotopes can be found in Table 3-1. 
Table 3-1

Isotope Inventory

\begin{tabular}{|c|c|}
\hline Isotope & $\begin{array}{c}\text { Inventory Per } \\
\text { Barrel, Ci }\end{array}$ \\
\hline $\mathrm{Cs} \mathrm{137}$ & 1927.5 \\
\hline $\mathrm{Pu} 241$ & 1869 \\
\hline $\mathrm{Sr} \mathrm{90}$ & 1189.3 \\
\hline $\mathrm{Kr} 85$ & 154.2 \\
\hline $\mathrm{H} 3$ & 8.75 \\
\hline
\end{tabular}

\subsection{ESTIMATED RELEASES}

There is little documentation available that discusses leakage of fission products from the fuel into the canister water and gas space. Some sipping of canisters took place in 1983. A weekly highlights report noted that some radioisotope levels were lower than expected, with a maximum $0.31 \mathrm{Ci}$ of $\mathrm{Cs} 137$ and an average of $0.066 \mathrm{Ci}$ Cs 137 per canister barrel. The 1983 sipping activity is also described in a controlled notebook. In addition, the leach rate of Cs 137 from open canistered fuel in the KE Basin has been evaluated and compared to the 1983 canister sipping data. This data is further discussed in Appendix A.

Using the data discussed in Appendix A, the following isotope contents are assumed to leach from the fuel into the water and gas space of a KW barrel and to quickly release into the basin when the canister is opened. 
Table 3-2

Assumed Fission Product Leached from Fuel

\begin{tabular}{|c|c|c|}
\hline Isotope & $\begin{array}{c}\text { Average } \\
\text { (Expected) }\end{array}$ & $\begin{array}{c}98 \% \\
\text { Probability Value }\end{array}$ \\
\hline $\mathrm{Cs} \mathrm{137}$ & $0.696 \mathrm{Ci}$ & $3.71 \mathrm{Ci}$ \\
\hline $\mathrm{Sr} 90$ & $0.431 \mathrm{Ci}$ & $2.30 \mathrm{Ci}$ \\
\hline $\mathrm{Kr} 85^{3}$ & $0.056 \mathrm{Ci}$ & $0.30 \mathrm{Ci}$ \\
\hline $\mathrm{H} 3$ & $0.003 \mathrm{Ci}$ & $0.017 \mathrm{Ci}$ \\
\hline
\end{tabular}

Cs 137 is the dominant water soluble isotope and is used below to characterize basin water activity changes during fuel sampling.

\subsection{ANALYSIS OF RELEASES}

Release of activity will result in an increase in KW Basin activity and an offsite release of airborne activity via the basin ventilation system. The impact depends on water volumes, ion exchange capacity, and ventilation flow rates. Canister decapping will take place in the transfer channel which is located between the south loadout pit and the main basin. The channel is not isolated from the loadout pit; thus, the total volume of the channel and the loadout pit are considered together. The area of the transfer channel is approximately $23 \mathrm{ft}^{2}$ with a nominal water depth of $16 \mathrm{feet}$, resulting in a volume of approximately $367 \mathrm{ft}^{3}$. The area of the loadout pit is approximately $64.3 \mathrm{ft}^{2}$ with a nominal water depth of $21 \mathrm{feet}$, resulting in a volume of approximately $1351 \mathrm{ft}^{3}$. Thus, the total volume is approximately $1718 \mathrm{ft}^{3}$ (Conn 1994). However, to be more conservative and to account for equipment located in the water, a volume of $1600 \mathrm{ft}^{3}$ is used in this report.

The transfer channel and the loadout pit are located in the high bay portion of the KW Basin facility. The high bay has an area of approximately $5450 \mathrm{ft}^{2}$ and a ceiling height of $38 \mathrm{feet}$. Thus, the building volume is $5450 \mathrm{ft}^{2} \times 38 \mathrm{ft}=207,100 \mathrm{ft}^{3}$, or 3.785 liters/gallon $\times 7.48$ gallons $/ \mathrm{ft}^{3} \times 207,100 \mathrm{ft}^{3}=5,860,000$ liters. The high bay is serviced by two exhaust ventilation units. The latest air flow tests gave a total flow of 25600 CFM for the units over the high bay. (Conn 1994)

Table 3-3 lists the important parameters involved in the analysis.

\footnotetext{
${ }^{3}$ Actual activity levels should be lower due to hydrogen generation. See Appendix B.
} 
Table 3-3

KW Basin Parameters

\begin{tabular}{|l|l|}
\hline \multicolumn{1}{|c|}{ Parameter } & \multicolumn{1}{c|}{ Value } \\
\hline Basin Water Volume & $1,000,000$ Gallons or 3.785E6 liters \\
\hline Loadout Pit Water Volume & $1600 \mathrm{cu} \mathrm{ft}$ or 12,000 gallons (10 by $10 \mathrm{ft}$ by 16 ft deep) \\
\hline Ventilation & $25,600 \mathrm{CFM}$ in the high bay \\
\hline Ion Exchanger Flow & $150 \mathrm{GPM}$ \\
\hline Ion Exchanger Efficiency & $99 \%$ \\
\hline
\end{tabular}

\subsubsection{Loadout Pit Water Cs 137 Activity}

The procedure that will be used to take fuel samples begins by moving canisters to the loadout pit where canister barrels will be uncapped. The barrel that is uncapped will release Cs 137 and other isotopes into the pit water. The soluble isotopes will remain in solution in the water and are amenable to removal by the ion exchangers. Insoluble isotopes, uranium oxides, and debris will tend to remain in the barrel as a fuel element is removed and placed in the transport cask. However, some of this material may come out of the barrel and settle to the bottom of the pit as sludge. The largest source of activity increase in the main basin is expected to be soluble radioisotopes such as Cs 137 that remain in solution in the pit water.

The soluble isotopes released into the pit will spread and mix with loadout pit water due to thermal currents and agitation by work activity and IXM flow. The peak Cs 137 activity can be calculated assuming instant release from the canister barrel and fast mixing.

$$
\begin{aligned}
\text { Peak Cs Activity }= & 3.71 \mathrm{Ci} /(12,000 \mathrm{gal} \times 3.785 \text { liters/gallon }) \\
& * 1 \mathrm{E} 6 \mu \mathrm{Ci} / \mathrm{Ci} \\
= & 82 \mu \mathrm{Ci} / \mathrm{L}
\end{aligned}
$$

The activity will be twice this value if two of the canister barrels are opened in a short interval of time and both release $98 \%$ probable limit Cs 137 activity into the

\footnotetext{
${ }^{4} A$ conservative water volume of $1,000,000$ gallons is used to calculate activity concentration in the main basin, while a higher value of $1,200,000$ gallons is used to estimate basin water cleanup times.
} 
pit. It is highly unlikely that two barrels will sequentially release this amount of activity.

The procedure that will be used to remove soluble fission product from the basin water is to pump 150 GPM of loadout pit water from a decapping station just inside and below the transfer channel gate to the ion exchanger modules (IXMs). The time to pump 12,000 gallons of loadout pit water at $150 \mathrm{GPM}$ is 80 minutes. If water flowing to the IXM is replaced by low activity water from the main basin, and this water mixes well with the loadout pit water, the time to remove $90 \%$ of the soluble isotopes from the loadout pit water is the time needed to turn over the water twice, i.e., 2 times 80 minutes or about 3 hours. Figures 2-1 and 2-2 show this transient response of the loadout pit Cs 137.

The above data and Figures 2-1 and 2-2 assume rapid, uniform mixing of the soluble isotopes in the loadout pit water. This may not be the case, as the canisters will be open low in the transfer channel in a decapping station with the IXM taking suction from a manifold in the decapping station. This arrangement should result in lower than average isotope concentrations at the loadout pit water surface and higher than average concentrations entering the IXM. The assumption of uniform mixing is conservative.

The loadout pit Cs 137 activity is estimated to result in dose rate at the water surface of $5 \mathrm{mr} / \mathrm{hr}$ for each $100 \mu \mathrm{Ci} / \mathrm{L}$ (See Appendix C).

\subsubsection{Main Basin Water Cs 137 Activity}

In the past, the $\mathrm{KW}$ Basin Cs 137 concentrations have been as high as $1 \mu \mathrm{Ci} / \mathrm{L}$ in 1993 , to a present day steady low of $0.05 \mu \mathrm{Ci} / \mathrm{L}$ (Burke, Dixon). A reasonable allowable limit during canister sampling is $0.5 \mu \mathrm{Ci} / \mathrm{L}$; this is 10 times the present day low, but half the 1993 high value. This results in an allowable increase of $0.45 \mu \mathrm{Ci} / \mathrm{L}$.

There are two sources of Cs 137 activity in the main basin:

1. The Cs 137 entering the basin from the several thousand canisters stored in the basin. Based on a steady, present day concentration of $0.05 \mu \mathrm{Ci} / \mathrm{L}$ and highly efficient IXM's, this source is estimated to be: 


\begin{tabular}{|c|c|c|}
\hline Cs 137 Activity & $=$ & $\begin{array}{l}(0.05 \mu \mathrm{Ci} / \mathrm{L}) \times(0.99 \mathrm{LXM} \text { efficiency }) \times \\
(150 \mathrm{GPM}) \times(3.785 \text { liters } / \text { gallon })\end{array}$ \\
\hline
\end{tabular}

2. The Cs 137 not being removed by the IXM. Section 3.5.2 discusses the preferred method of operating the IXM's during fuel sampling. This method should result in $99 \%$ removal of soluble isotopes from the loadout pit water before it flows into the main basin, i.e., only $1 \%$ of the Cs 137 released from an open canister will have a pathway into the main basin. This will result in the following incremental increase in main basin Cs 137 activity:

$$
\begin{aligned}
\text { Cs } 137 \text { Activity }= & (0.01) \times(3.71 \mathrm{Ci}) /(1,000,000 \text { gallons }) \\
& /(3.785 \text { liters } / \text { gallon }) \\
& \times(1 \mathrm{E} 6 \mu \mathrm{Ci} / \mathrm{Ci}) \\
= & 0.01 \mu \mathrm{Ci} / \mathrm{L}
\end{aligned}
$$

This activity increase is small compared to the allowable of $0.45 \mu \mathrm{Ci} / \mathrm{L}$; approximately 40 barrels, each releasing $3.71 \mathrm{Ci}$ of $\mathrm{Cs} 137$, could be opened over a short period of time without exceeding the allowable increase in basin water Cs 137 activity. The impact of opening barrels that release expected values is significantly less than this.

The time to circulate all of the $1,200,000$ gallon main basin twice through the loadout pit, to the IXM, and back to the main basin is 16,000 minutes or about 11 days. This is the time period needed to remove $90 \%$ of the Cs 137 transferred to the basin when canisters are opened.

Figures 2-1 and 2-2 show the transient response of the main basin. Figure 2-2 depicts a practical limit for canister sampling - four canister barrels during the first half of each day for five days, with two barrels being opened at a time, then another two opened three hours later. Figure 2-2 is based on the 20 canister barrels containing the expected or average Cs 137 level listed in Table 3-2 since the average is more representative of a large number of canister barrels.

The total activity in the basin water could be greater than that shown in Figures 2-1 and 2-2. The increase will be proportional to the activity of other isotopes that are released from the barrel and remain in solution in the basin water. Insoluble isotopes will either remain in the barrel or contribute to basin sludge and will be shielded from the workings areas by basin water. On the other hand, basin activity could be higher or lower depending on whether the leaching rate is more or less than the rate developed in Appendix A and used for Table 3-2. 
Figures 2-1 and 2-2 show the importance of having high ion exchanger isotope removal efficiency and treating water taken directly from the loadout pit. The KW Basin is provided with both ion exchange columns and ion exchange modules (IXMs). Only IXMs are capable of handling flow directly from the loadout pit and returning the deionized water to the main basin. Initially, IXM ion removal efficiency is $99 \%$ or better. However, once the IXM nears saturation, efficiency falls off rapidly. IXM efficiency is discussed in Section 3.4.5.

The following are steps that can be taken to maximize high isotope removal efficiency during fuel sampling:

1. Start SNF characterization with two IXM's available: one on-line and active, and a new IXM on bypass ready to be valved into service when efficiency of the on-line IXM deteriorates or the accumulated Cs 137 removal exceeds limits (See Section 3.4.5).

2. Sample daily to monitor LXM efficiency while there are open canisters in the loadout pit.

\subsubsection{Airborne Activity}

Present fuel sampling plans call for venting the canister barrels in the KW Basin weasel pit before the canisters are moved to the loadout pit to be decapped. There is a potential for increased airborne activity levels in the KW Basin facility whenever a barrel containing the gaseous isotopes listed in Section 3.3 is opened. It should be noted that air circulation in the KE Basin is not especially good. Supplemental ventilation such as fans should be located in the vicinity of the weasel pit and other locations when venting of barrels takes place.

Because of the $\mathrm{KE}$ Basin ventilation conditions, it is not possible to estimate the size or duration of a cloud of airborne activity if it is released in the basin water and rises to the air space above the water. Ruben assumes a $718 \mathrm{ft} 3$ or $2 \mathrm{E} 7 \mathrm{ml}$ hemisphere that persists for one minute. The diameter of this hemisphere is 14 feet.

$\mathrm{H} 3$ is a potential airborne activity, but is usually found in the form of tritiated water. $\mathrm{Kr} 85$ is a noble gas and will not combine to form non-gaseous molecules. Assuming that the quantities of $\mathrm{H} 3$ and $\mathrm{Kr} 85$ described in Section 3.3 are released and mix instantly in the air space, the peak activity in the high bay air space is calculated to be: 
For $\mathrm{H3}: \quad(0.017 \mathrm{Ci}) /(2 \mathrm{E} 7 \mathrm{ml}) \times(1 \mathrm{E} 6 \mu \mathrm{Ci} / \mathrm{Ci})=8.5 \mathrm{E}-4 \mu \mathrm{Ci} / \mathrm{ml}$

For $\mathrm{Kr} 85: \quad(0.30 \mathrm{Ci} / 2 \mathrm{E} 7 \mathrm{ml}) \times(1 \mathrm{E} 6 \mu \mathrm{Ci} / \mathrm{Ci})=1.5 \mathrm{E}-02 \mu \mathrm{Ci} / \mathrm{ml}$

The $\mathrm{H} 3$ activity is less than the Derived Air Concentration (DAC) for $\mathrm{H} 3$, while the $\mathrm{Kr} 85$ activity level is more than the DAC limit of $1 \mathrm{E}-4 \mu \mathrm{Ci} / \mathrm{cc}$ for $\mathrm{Kr} 85$. It should be noted, however, that the DAC limit is based on workers being exposed to the $\mathrm{Kr}$ 85 cloud for 2000 hours a year and that this amount of exposure results in an annual dose equivalent to the skin equal to the allowable limit of $50 \mathrm{rem}$ (the limiting condition for $\mathrm{Kr} 85$ is skin dose, not inhalation). As a result, the skin dose for each minute of exposure to a $\mathrm{Kr} 85$ cloud of $1.5 \mathrm{E}-2 \mu \mathrm{Ci} / \mathrm{ml}$ is:

$$
\begin{aligned}
& (1 \mathrm{~min}) /(60 \mathrm{~min} / \mathrm{hr} \times 2000 \mathrm{hr}) \times(1.5 \mathrm{E}-02 \mu \mathrm{Ci} / \mathrm{ml}) /(1 \mathrm{E}-4 \mu \mathrm{Ci} / \mathrm{cc}) \times(50 \mathrm{rem}) \\
& =0.0625 \mathrm{rem}
\end{aligned}
$$

Compared to the annual limit of $50 \mathrm{rem}$, the $98 \%$ probability canister barrel $\mathrm{Kr} 85$ release is only a fraction of the limit and contains margin for large releases and longer cloud persistency. Furthermore, this amount of exposure assumes that all of the $\mathrm{Kr} 85$ stays in the canister vent space and is quickly released rather than slowly vented to the environment or diluted by hydrogen during the uranium corrosion process. Thus, respiratory protective equipment or special protective clothing should not be required when venting or opening canister barrels. However, precautions such as using fans to improve ventilation and using the vent valves to slowly release the canister barrel gases before decapping should be taken (See Section 3.5):

\subsubsection{Transuranic (TRU) Activity ${ }^{5}$}

Based on the 1983 Mark I canister sipping data, Pu 239, Pu 240 and Am 241 accounts for most of the TRU content in the canister barrels. Using the peak fissile data developed in Appendix A and the 1983 sipping data, Table 3-4 has been developed to show the estimated potential effect of opening a canister barrel with a large amount of releasable TRUs. The KW Basin activity levels shown in Table 3-4 assume that all the TRUs are soluble and mix with the loadout pit water and that the water is processed by the IXMs with $90 \%$ TRU removal efficiency and then discharged into the main basin. The LXMs in KE Basin exhibit a typical removal efficiency of $90 \%$ for TRU isotopes during sludge pumping activities (when there is higher

\footnotetext{
${ }^{5}$ Based on information provided by S.P. Burke.
} 
amount of suspended particulates) and much higher efficiencies at other times. Furthermore, most of the TRUs will be insoluble and remain in the loadout pit or be discharge to the main basin as sludge. It is estimated that $95 \%$ of the TRU particulates are less than 3 microns. Most of these will be swept up by the IXM flow taken from the vicinity of the decapping station. A 1984 study of the need for IXM prefilters concluded that particulates from $6 \% \mathrm{Pu} 240$ fuel did not have a significant effect on IXM life. (Bogert) A test based on 12\% fuel was prepared, but never run.

The combined Pu239/240 activity shown in Table 3-4 is $1.55 E-3 \mathrm{Ci}$.

Table 3-4

Estimated Maximum (98\% Probability Value) Releasable TRU in a Barrel

\begin{tabular}{|l|l|l|l|l|l|}
\hline \multicolumn{1}{|c|}{ Isotope } & \multicolumn{1}{|c|}{$\begin{array}{c}\text { Mass } \\
\text { Fraction }\end{array}$} & $\begin{array}{c}\text { Specific } \\
\text { Activity } \\
\text { Ci/gm }\end{array}$ & $\begin{array}{c}\text { Fissile } \\
\text { Material } \\
\text { gms }\end{array}$ & $\begin{array}{c}\text { Fissile } \\
\text { Activity } \\
\text { Ci }\end{array}$ & $\begin{array}{c}\text { Resulting } \\
\text { KW Basin } \\
\text { Activity } \\
\mu \text { Ci/L }\end{array}$ \\
\hline Am 241 & 0.010 & 3.4276 & 0.0087 & $2.975 \mathrm{E}-2$ & $7.860 \mathrm{E}-4$ \\
\hline Pu 239 & 0.952 & 0.0621 & 0.8263 & $5.132 \mathrm{E}-2$ & $1.356 \mathrm{E}-3$ \\
\hline Pu 240 & 0.038 & 0.2280 & 0.0330 & $7.519 \mathrm{E}-3$ & $1.986 \mathrm{E}-3$ \\
\hline TOTAL & 1.0 & & 0.868 & $1.563 \mathrm{E}-1$ & $2.341 \mathrm{E}-3$ \\
\hline
\end{tabular}

\subsubsection{Ion Exchanger Module Considerations}

The IXMs have two limitations that need to be considered when evaluating the effect of opening SNF canisters in KW Basin; the amount of Cs 137 that can be removed without significantly losing ion removal efficiency and the limit on accumulation of transuranics (TRUs) in the IXM before the IXM must be considered TRU waste, and treated as such when it is replaced.

Cs 137 Capacity The IXM Cs 137 removal efficiency is in excess of $99 \%$ when not saturated with Cs 137. Figure 3-1 shows Cs 137 removal efficiency versus Cs 137 loading for KE Basin IXM. The figure shows that efficiency remains above $99 \%$ for $\mathrm{Cs} 137$ loadings up to $80 \mathrm{Ci}$ then drops off rapidly. The $\mathrm{KW}$ Basin IXMs are of the same type as the KE Basin unit and should have the same characteristics.

The information contained in Figure 3-1 shows that a new or partially depleted DXM has a Cs 137 removal capacity well in excess of the $98 \%$ probability release from a 
single canister barrel opening. The data used for Figure 3-1 does not include the potential effect of other chemicals that may be released into the loadout pit water when a canister barrel is opened. Specifically, the canister barrel contains potassium nitrite whose effect on the IXMs is unknown. Therefore, the active IXM should be removed from service while there is still capacity margin in the event that the Cs 137 release significantly exceeds the estimated $98 \%$ probability value or the potassium nitrite has deleterious effects, at least until several canister barrels have been uncapped and the statistics are found to be similar or more favorable than those used for this report. An initial margin of $40 \mathrm{Ci}$ is suggested.

TRU Capacity The IXMs have a total Pu 239 limit of 225 grams and a TRU limit of $100 \mathrm{nCi} /$ gram based on total IXM weight.' Table 3-4 shows that the Pu 239 limit is not of concern. On the other hand, the gross weight of an IXM is $42,000 \mathrm{lbs}$ or $463 \mathrm{x}$ $42,000=1.95 \mathrm{E} 7 \mathrm{grams}$. This results in a TRU capacity of $100 \mathrm{nCi} / \mathrm{g} \times 1.95 \mathrm{E} 7 \mathrm{grams}$ $=1.95 \mathrm{E} 9 \mathrm{nCi}=1.95 \mathrm{Ci}$. This is a factor of 12 greater than the estimated maximum canister barrel TRU release shown in Table 3-4, an adequate margin to account for uncertainty and to allow several barrels with high releasable activity to be opened.

'Data and methodology provided by S.P. Burke. 


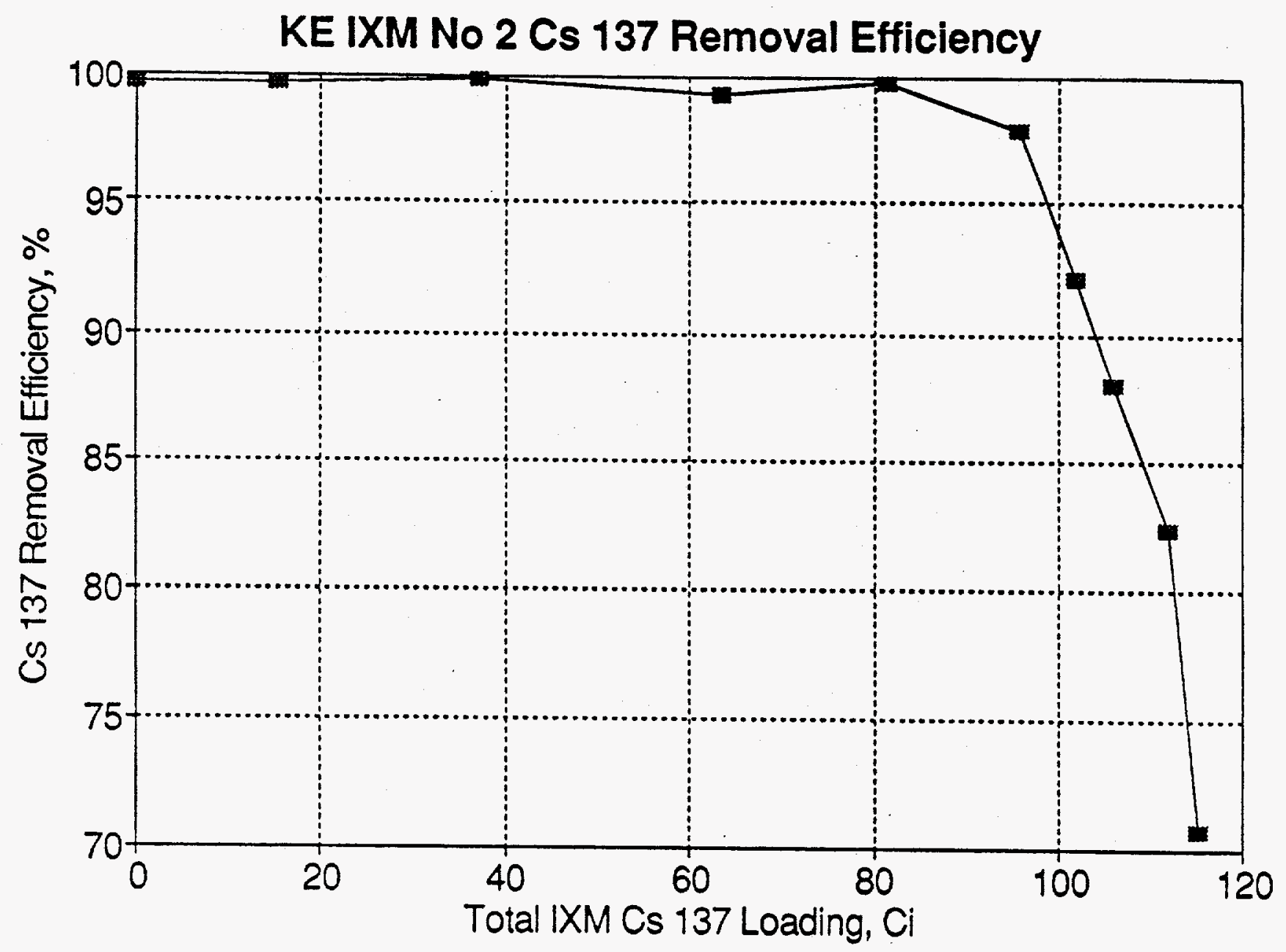

Figure 3-1

KE IXM No 2 Cs 137 Removal Efficiency

(From Data Provided by S.P. Burke) 


\subsection{MITIGATION}

There are actions, such as canister gas bleedoff and sampling, and basin water clean-up via ion exchange, that can be taken to minimize high activity levels in $\mathrm{KW}$ Basin during fuel sampling. These are discussed below.

\subsubsection{Canister Gas Bleedoff and Sampling}

Each barrel cap is provided with two vent valves. Appendix B discusses the precautionary step of using the peripheral valve to slowly vent the barrel gas and fill the gas space with water. This will reduce the potential for high activity levels in the ventilation exhaust in case there are significant quantities of fission gases in the barrel gas space. Some of the gas can be collected and the activity, such as $\mathrm{Kr} 85$, determined. If there has not been significant $\mathrm{Kr} 85$ leakage or dilution by hydrogen gas generation in the barrel, and if the $\mathrm{Kr} 85$ activity is on order of $200 \mu \mathrm{Ci} / \mathrm{cc}$, then the amount of activity leached from the fuel during storage is approximately the $98 \%$ probability value listed in Table 3-2. However, significant Kr 85 release will be the result of uranium corrosion and will be accompanied by generation of hydrogen gas. The likelihood is high that the $\mathrm{Kr} 85$ activity will be diluted by the hydrogen. In this case, a gas sample can still be used to determine the $\mathrm{Kr} 85$ activity remaining in the barrel.

The concentration of $\mathrm{H} 3$ will not be a good overall indicator of fission product release from the fuel. It can diffuse through metallic uranium and zirconium; it can take the form of tritiated water; or it can react to form uranium hydride. 


\subsubsection{IXM Flow Path}

The loadout pit is separated from the main basin by a metal gate located in the transfer channel connecting the loadout pit to the main basin. The gate is in two parts with each half attached to a transfer channel wall. The gate remains closed at all times. Transfer of material between the loadout pit and main basin is via an opening created by the halves of the gate: a narrow opening in the upper 11 feet to accommodate the movement of a grapple and a wide opening in the lower $31 / 2$ feet to accommodate a fuel canister or other large object held by the grapple. The opening is covered by neoprene flaps which move aside when a grapple and transfer basket move through the gate. Most of the uncapping work will be done in a work box just inside and below the gate. The flow to the IXM's is from this work location.

When a canister barrel is opened in the loadout pit, there is a potential for a large increase in radionuclide activity in the loadout pit water. The gate and neoprene flaps play an important role in preventing flow of water and transfer of radionuclides from the loadout pit directly into the main basin due to diffusion and currents caused by work activities and thermal effects. This flow path can be prevented by establishing a forced circulation flow path from the main basin into the loadout pit. This can be achieved by taking all 150 GPM IXM flow from the loadout pit and returning it back to the main basin. A reasonably tight gate and neoprene assembly is required.

The net cross-sectional flow area, less the moveable barrier provided by the neoprene, is approximately $15 \mathrm{ft}^{2}$. If it is assumed that the neoprene is $95 \%$ effective in blocking flow when the gate is clear of a grapple and its load, then the net flow area for $150 \mathrm{GPM}$ of flow from the main basin to the loadout pit is $0.75 \mathrm{ft}^{2}$. This area results in an average velocity of $0.4 \mathrm{fps}$, a value high enough to negate diffusion and currents in the loadout pit. 


\subsection{REFERENCES}

1. Bogert, S.R., “KW IXM Prefilter Assessment,” UNI-3303, February 1, 1985.

2. Burke, Steve (WHC E\&EDL), Private Communication, November 4, 1994.

3. Conn, K.R., "Calculation of Water Level in Gas Traps on MK-II Fuel Storage Canisters at 105-KW," WHC-SD-NR-ANAL-009, March 16, 1992.

4. Conn, K.R., "Comments on Draft Report - Assessment of Decapping Canisters at KWest," December 14, 1994.

5. Dixon, W. T., Letter to S. H. Wisness, "Calendar Year 1993 Radioactive Discharges," 4/19/94.

6. Kratzer, W.K., Memorandum to J.K. Ostic, "Effect of Decapping Mark II Canisters at Each of the Basins With and Without Auxiliary Ion Exchange Modules," April 20, 1993.

7. Morris, K.R. Memorandum to L.L. Blehm, "Response to Fuel Storage Database Preparation," January 30, 1992.

8. Pitner, A. L. WHC Internal Memo to R.P. Omberg, "Preliminary Results of Underwater Visual Survey of K East Basin Fuel," November 29, 1994.

9. Rockwell, Theodore, Editor., "Reactor Shielding Design Manual," D. Van Nostrand Company, Inc., Princeton, N.J., 1956.

10. Ruben, R.H., WHC Memo 33660-95-RHR-001, "Activity and Dose Estimates for Kr 85 Gas Escaping from K-Basin Spent Fuel Canisters," January 3, 1995.

11. Smet, D.B., "MK II Ultrasonic Testing Investigation," WHC-SD-NR-ER-094, March 23, 1992.

12. Stevens, P.F., "N Reactor/Single Pass Reactor Fuel Characterization Shipments Safety Evaluation for Packaging," WHC-SD-TP-SEP-028, August 31, 1994. 
WHC-SD-SNF-ES-006, REV. 0

13. Weber, J. W., "Review of Consequences of Uranium Hydride Formation in NReactor Fuel Elements Stored in the K-Basins," 9/15/94.

14. WHC-CM-7-5, Appendix C, Derived Concentration Guides, Revision 1, July $15,1993$. 


\section{APPENDIX A \\ ESTIMATED FISSION PRODUCT RELEASES FROM SPENT FUEL}

\section{A.1 FISSION PRODUCT INVENTORY}

Table A3-1 of WHC-SD-TP-SEP-028 provides a list of the highest expected activity levels for an inner and outer $N$ Reactor fuel element. Since there are seven fuel assemblies (inner and outer) per sealed barrel, the inventory is seven times the values listed in Table A3-1. The significant isotopes are:

\begin{tabular}{|l|r|r|r|}
\hline \multirow{2}{*}{ Isotope } & \multicolumn{2}{|c|}{ Activity, Ci } & \multirow{2}{*}{$\begin{array}{c}\text { Normalized } \\
\text { to Cs 137 }\end{array}$} \\
\cline { 2 - 3 } & Per Fuel Assembly & \multicolumn{1}{|c|}{ Per Barrel } & \\
\hline Cs 137 & 275.36 & 1927.5 & 1.0 \\
\hline Sr 90 & 169.9 & 1189.3 & 0.617 \\
\hline Kr 85 & 22.03 & 154.2 & .08 \\
\hline H3 & 1.25 & 8.75 & .0045 \\
\hline
\end{tabular}

\section{A.2 FUEL LEAKAGE DATA}

The primary source of activity increase in the KW Basin during fuel sampling will be the fission product that has leached from the spent fuel, through the broken Zircaloy cladding, and into the water and gas space of the sealed storage barrels. Two sources of information are available to estimate fuel leak rates for the KW MKII canisters: (1) sipping of MK I canisters in the KW Basin in December 1982, and (2) recent estimates of Cs 137 leaching into the KE Basin from open canisters. These are discussed below. 


\section{A.2.1 MK I Canister Sampling}

Sipping of Mark I canisters ${ }^{1}$ took place in late 1982. A weekly highlights report (Nicklas) noted that some radioisotope levels were lower than expected, averaging $0.066 \mathrm{Ci}$ of Cs 137 per barrel with a maximum of $0.31 \mathrm{Ci}$ of $\mathrm{Cs} 137$ per canister. An unidentified page from what appears to be an activities report (Bechtold) discusses the same radioisotope levels, but cautions that a real worst case release may be twelve times the maximum sipping case. Another letter report (Kratzer) uses the $0.31 \mathrm{Ci}$ of Cs 137 fuel release to evaluate the effect of decapping Mark II canisters and converts this value to a leach rate of $600 \mu \mathrm{Ci} /$ day per barrel. These correspondences (Nicklas, Bechtold and Kratzer) are included as part of this Appendix as Attachments 1, 2 and 3.

Data from early 1983 Mark I canister sipping is contained in controlled notebook UNI-N-462. Data from page 104 of this notebook are shown in Tables A-1 and A-2. The data in these tables shows several interesting results:

1. Table A-1 shows all the data from UNI-N-462. There is a large difference between the minimum and maximum values in all data categories. Also, the standard deviations are larger than the average values in almost all categories. In essence, the data does not have a standard distribution. However, if a standard distribution is assumed, the three sigma or $95 \%$ probability value values are remarkably close to the maximum observed values for all categories.

2. There appears to be no correlation between the number of breaks in the fuel cladding and the amount of fission product and fissile material leached into the canister barrels.

3. Table A-2 shows all the data from UNI-N-462 except the three canisters with the lowest Cs 137 readings, canisters 2550, 1197 and 916 . In essence, the data in Table A-2 is skewed toward the higher 1983 sampling values and the differences between minimum and maximum have been reduced by almost an order of magnitude, giving the data a more standard distribution. The $98 \%$ probability values exceed the maximum observed categories in all categories.

\footnotetext{
'Mark I canisters use aluminum barrels, but are sealed and store $\mathrm{N}$ Reactor spent fuel in water containing potassium nitrite inhibitor with a nitrogen gas space. These conditions are similar to conditions in the stainless steel Mark II canisters; therefore, similar release rates from the fuel into the sealed barrel should occur for Mark II canisters.
} 
In summary, the 1983 Mark I canister sipping data is useful data for predicting the amount of fission product and fissile material leached into the Mark $\Pi$ canister barrels by 1995 . The $98 \%$ probability levels shown on Table A-2 represent the high range of leaching in sealed canisters containing corrosion inhibitor in early 1983 when sipping took place.

It has been approximately 12 years since the Mark I canisters were sipped. Burke ${ }^{2}$ has developed a method to estimate the projected $1995 \mathrm{Cs} 137$ levels in sealed canisters. His estimate is based on developing a daily leaching rate, assuming that the rate has remained constant since 1983 and straight line extrapolating the date to 1995 (approximately 4130 days). Results, based on $98 \%$ probability value data of Table A-2, are shown in Table A-3. The largest amount of Cs 137 leached into a canister barrel using the 1983 sipping data in this manner is $3.71 \mathrm{Ci}$ and the largest amount of fissile material leached in a canister barrel is $0.868 \mathrm{gms}$.

\section{A.2.2 Cs 137 Leaching Rates in KE Basin}

The KE Basin is storing $N$ Reactor spent fuel in open canisters and the basin water does not contain a corrosion inhibitor. Uranium corrosion and fission product release (leach) ${ }^{3}$ into the KE Basin water should be similar if not greater than the corrosion and leaching rates in the sealed $\mathrm{KW}$ canisters.

The leaching rate of Cs 137 into the KE Basin water has been determined by accounting for the $\mathrm{Cs} 137$ removed by the K Basin ion exchanger columns and modules (Burke). The results are shown graphically in Figure A-1. The leach rate varies considerably with basin water temperature and conductivity. The range is from less than $1 \mathrm{Ci}$ per day for low temperature, low conductivity water, to $8 \mathrm{Ci}$ per day for high temperature, high conductivity water.

There are presently 3666 double barrel open canisters in the KE Basin. Using this quantity, a total basin canister leach rate of $8 \mathrm{Ci} /$ day converts to $8 \times 1,000,000$ $\mu \mathrm{Ci} /$ day $/(2 \times 3666)=1100 \mu \mathrm{Ci} /$ day per barrel. The low leach rate of $1 \mathrm{Ci} /$ day converts to $138 \mu \mathrm{Ci} /$ day. These estimates do not account for the variation in fuel damage observed in KE Basin.

\footnotetext{
${ }^{2}$ FAX communication, S. P. Burke to F.J. Mollerus.

${ }^{3}$ Leaching is the transfer of fission products, uranium, and transuranics from the fuel's uranium metal through damaged cladding into the surrounding water caused by mechanisms such as metalwater corrosion and diffusion.
} 
There are several estimates of the extent of fuel damage in the KE Basin.

- A 1981 visual inspection (Bechtold) examined 4993 canisters in the KE Basin. It was reported that 1484 of the canisters had fuel with leaks or breaks and that $2.987 \%$ of the observed fuel was leaking or broken. The observed and predicted multiplicity of leaking or broken fuel is shown in Table A-4. The observations were from above the fuel. The report concludes that twice as many fuel elements could have had leaking or broken fuel and twice as many canisters could have been affected.

- A 1994 underwater video survey of KE Basin fuel (Pitner) reports that over $90 \%$ of the canisters contain at least one ruptured fuel element with $27 \%$ of the inner elements and $42 \%$ of the outer elements being breached to some extent. Furthermore, the report states that $6 \%$ of the canisters contain badly degraded fuel.

These observations show some variation in the percentage of badly damaged fuel. This may be due to the time frame between observations and the difficulty of viewing the entire surface of the fuel elements.

If the percentage of damaged fuel elements is a small fraction of the total number of fuel elements in the KE Basin, and it is assumed that damaged and undamaged fuel are randomly loaded into barrels, then the distribution of the number of fuel elements in a barrel will closely follow a Poisson distribution, as does the data in Table A-4. Poisson distribution can be used to compare the KE Basin leach rate data to the estimated $98 \%$ probability leach rate for $\mathrm{KW}$ canister barrels shown in Table A-3, $840 \mu \mathrm{Ci} /$ day.

Table A-5 shows the Cs 137 leach rate in a barrel versus probability of occurrence for three assumed percentages of badly failed fuel: 3,12 and the reported $6 \%$. The leach rate shown in Table A-5 assumes that the total basin leach rate is $4 \mathrm{Ci} /$ day, nearly the average shown in Figure A-1. The result show that the per barrel leach rate at $98 \%$ probability is approximately three times the $98 \%$ probability value of $842 \mu \mathrm{Ci} /$ day calculated for KW Basin canister barrels and is relatively independent of the percent failed fuel. The KE $98 \%$ probability estimate would be close to the KW $98 \%$ probability if the low end of the KE Basin leach rate, $1 \mathrm{Ci} /$ day, is used; it would be six times the KW $98 \%$ probability value if the larger end of the KE Basin leach rate date, $8 \mathrm{Ci} /$ day, is used. The $\mathrm{KE}$ Basin data does add some credibility to the KW 1983 sipping data and its straight line extrapolation to 1995, and serves a warning that higher KW Mark II releases could occur than those predicted from the 1983 sipping data. 


\section{A.3 ESTIMATED KW FUEL RELEASE}

This report uses the $98 \%$ probability values of Table A-3 to evaluate the potential increase in KW Basin radioactivity levels when opening Mark II canister barrels to sample fuel. These are peak values; the average values are also from Table A-3 and are expected to be more representative of multiple canister openings. The following summarizes these isotopes and fissile material. The other isotopes shown in Table 3-2 are based on these Cs 137 values and the normalization factors from Section A.1.

\begin{tabular}{|l|l|l|}
\hline & \multicolumn{1}{|c|}{ Average Values } & \multicolumn{1}{|c|}{$98 \%$ Probability Value } \\
\hline Cs 137 & $0.696 \mathrm{Ci}$ & $3.71 \mathrm{Ci}$ \\
\hline Fissile Material & 0.179 grams & 0.868 grams \\
\hline
\end{tabular}

These values should be conservative if:

- The potassium nitrite corrosion inhibitor is as effective as the uninhibited $\mathrm{KE}$ Basin water and has not aggravated the corrosion rate. Data on effectiveness of the corrosion inhibitor is not available.

- Other unidentified mechanisms have not accelerated corrosion in the KW Mark II canisters; since stainless steel is less reactive than aluminum, the stainless steel Mark II canisters should not be the source of an unidentified mechanism.

One source of non-conservatism is the possibility that the amount of uranium surface and intergranular cracks have increased since 1983 and have increased the overall corrosion rate of the uranium and leaching of fission product into the KW canisters. For this reason, the precautions described in Section 2.1 should be taken. 
WHC-SD-SNF-ES-006, REV. 0

Table A-1 All UNI-N-462 Sipping Data

\begin{tabular}{|c|c|c|c|c|c|c|c|c|c|c|c|}
\hline $\begin{array}{c}\text { CANISTRR } \\
\text { No. }\end{array}$ & BARREI & $\begin{array}{c}\mathbf{K R Y} \\
\mathbf{4}\end{array}$ & $\begin{array}{l}\text { CAP } \\
\text { DATE }\end{array}$ & $\begin{array}{l}\text { TOTAL } \\
\text { BREAKS }\end{array}$ & $\begin{array}{c}\text { Cs137 } \\
C 1\end{array}$ & $\begin{array}{c}\mathrm{Ca135} \\
\mathrm{C} 1\end{array}$ & $\begin{array}{c}\text { Co60 } \\
\mathrm{C} 1\end{array}$ & $\begin{array}{c}\mathrm{Mn54} \\
\mathrm{CI} \\
\end{array}$ & $\begin{array}{c}8590 \\
\text { Cl }\end{array}$ & $\begin{array}{l}\text { Fuel } \\
\text { gms }\end{array}$ & $\begin{array}{c}\text { P1se110 } \\
\text { qms }\end{array}$ \\
\hline 1292 & $T$ & 2201 & 513 & 1 & $3.10 \mathrm{E}-01$ & $2.80 \mathrm{E}-02$ & $0.00 \mathrm{E}+00$ & $0.00 E+00$ & $1.90 \mathrm{E}-01$ & $1.05 E+01$ & $7.50 \mathrm{E}-02$ \\
\hline 959 & $\mathbf{U}$ & 2852 & 464 & 3 & $1.89 \mathrm{E}-01$ & $3.40 \mathrm{E}-02$ & $2.10 \mathrm{E}-04$ & $2.00 \mathrm{E}-04$ & $2.40 \mathrm{E}-02$ & $6.43 E+00$ & 4. $30 \mathrm{E}-02$ \\
\hline 1230 & U & 2127 & 519 & 1 & $1.30 \mathrm{E}-01$ & $9.70 \mathrm{E}-03$ & $0.00 \mathrm{E}+00$ & $1.20 \mathrm{E}-04$ & $8.80 \mathrm{E}-02$ & $5.22 E+00$ & $4.00 \mathrm{E}-02$ \\
\hline 2550 & $T$ & 3016 & 251 & 1 & $8.40 \mathrm{E}-02$ & $1.80 \mathrm{E}-02$ & $0.00 \mathrm{E}+00$ & $3.20 \mathrm{E}-04$ & $4.66 \mathrm{E}-02$ & $2.22 E+00$ & $1.40 \mathrm{E}-02$ \\
\hline 2670 & $T$ & 2942 & 251 & 1. & $7.60 \mathrm{E}-02$ & 1. $35 \mathrm{E}-02$ & $6.50 \mathrm{E}-04$ & $7.00 \mathrm{E}-04$ & $4.60 \mathrm{E}-02$ & $2.30 E+00$ & $1.60 \mathrm{E}-02$ \\
\hline 1292 & $\mathrm{U}$ & 2201 & 513 & 1 & $6.20 \mathrm{E}-02$ & $6.20 \mathrm{E}-03$ & $0.00 \mathrm{E}+00$ & $1.40 \mathrm{E}-05$ & $3.60 \mathrm{E}-02$ & $1.85 E+00$ & $1.20 \mathrm{E}-02$ \\
\hline 2670 & $\mathrm{U}$ & 2942 & 251 & 1 & $4.90 \mathrm{E}-02$ & $1.00 \mathrm{E}-02$ & $3.70 \mathrm{E}-04$ & $2.00 \mathrm{E}-04$ & $2.60 \mathrm{E}-02$ & $1.20 E+00$ & $7.20 \mathrm{E}-03$ \\
\hline 1825 & ס & 2480 & 498 & 1 & $4.40 E-02$ & $5.00 \mathrm{E}-03$ & $1.90 \mathrm{E}-04$ & $9.30 \mathrm{E}-05$ & $2.80 \mathrm{E}-02$ & $1.50 \mathrm{E}+00$ & $1.10 \mathrm{E}-02$ \\
\hline 1091 & $\mathbf{U}$ & 2201 & 510 & 2 & $3.90 \mathrm{E}-02$ & $3.90 \mathrm{E}-03$ & $1.10 \mathrm{E}-04$ & $9.70 \mathrm{E}-05$ & $2.30 \mathrm{E}-02$ & $1.20 \mathrm{E}+00$ & $7.60 \mathrm{E}-03$ \\
\hline 1091 & $\mathbf{v}$ & 2201 & 512 & 2 & $3.80 \mathrm{E}-02$ & $3.10 \mathrm{E}-03$ & $4.50 \mathrm{E}-05$ & $4.90 \mathrm{E}-05$ & $2.50 \mathrm{E}-02$ & $1.40 \mathrm{E}+00$ & $1.05 \mathrm{E}-02$ \\
\hline 857 & $T$ & 3015 & 469 & 1 & $3.41 \mathrm{E}-02$ & $6.23 E-03$ & $5.96 \mathrm{E}-03$ & $3.01 \mathrm{E}-02$ & $4.20 \mathrm{E}-02$ & $1.33 \mathrm{E}+00$ & $9.40 \mathrm{E}-03$ \\
\hline 2283 & $\mathbf{U}$ & 3016 & 244 & 2 & $3.20 \mathrm{E}-02$ & $7.98 E-03$ & $3.70 \mathrm{E}-04$ & $2.80 \mathrm{E}-04$ & $1.50 \mathrm{E}-02$ & $6.90 \mathrm{E}-01$ & $3.50 \mathrm{E}-03$ \\
\hline 1035 & $T$ & 2127 & 528 & 2 & $3.06 \mathrm{E}-02$ & $3.20 \mathrm{E}-03$ & $5.10 \mathrm{E}-05$ & $1.60 \mathrm{E}-04$ & $1.60 \mathrm{E}-02$ & $8.00 \mathrm{E}-01$ & $4.70 \mathrm{E}-03$ \\
\hline 1035 & $\mathbf{T}$ & 2127 & 530 & 2 & $3.00 \mathrm{E}-02$ & $2.40 \mathrm{E}-03$ & $5.90 \mathrm{E}-05$ & $6.40 \mathrm{E}-05$ & $1.09 \mathrm{E}-01$ & $1.07 \mathrm{E}+00$ & $7.80 \mathrm{E}-03$ \\
\hline 1728 & v & 2480 & 946 & $\mathrm{BF}$ & $2.90 \mathrm{E}-02$ & $3.20 \mathrm{E}-03$ & $9.50 \mathrm{E}-05$ & $1.00 \mathrm{E}-04$ & $1.90 \mathrm{E}-02$ & $1.02 \mathrm{E}+00$ & $7.50 \mathrm{E}-03$ \\
\hline 2550 & v & 3016 & 251 & 1 & $5.40 \mathrm{E}-03$ & $1.30 \mathrm{E}-03$ & $2.54 \mathrm{E}-04$ & $1.32 \mathrm{E}-04$ & $2.70 \mathrm{E}-03$ & $1.25 \mathrm{E}-01$ & $6.80 \mathrm{E}-04$ \\
\hline 1197 & U & 2285 & 504 & 1 & $4.20 \mathrm{E}-03$ & $4.40 \mathrm{E}-04$ & $0.00 \mathrm{E}+00$ & $1.00 \mathrm{E}-04$ & $2.40 \mathrm{E}-03$ & $1.25 \mathrm{E}-01$ & $8.30 \mathrm{E}-04$ \\
\hline 916 & $\mathbf{T}$ & 3015 & 469 & 4 & $1.86 \mathrm{E}-03$ & $3.50 \mathrm{E}-04$ & $6.10 \mathrm{E}-04$ & $1.40 \mathrm{E}-04$ & $2.30 \mathrm{E}-03$ & $1.69 \mathrm{E}-01$ & $4.80 E-04$ \\
\hline \multicolumn{5}{|c|}{ MInImum } & $1.86 \mathrm{E}-03$ & $3.50 \mathrm{E}-04$ & $0.00 E+00$ & $0.00 \mathrm{E}+00$ & $2.30 \mathrm{E}-03$ & $1.25 \mathrm{E}-01$ & $4.80 E-04$ \\
\hline \multicolumn{5}{|c|}{ Maximum } & $3.10 \mathrm{E}-01$ & $3.40 \mathrm{E}-02$ & $5.96 E-03$ & $3.01 \mathrm{E}-02$ & $1.90 \mathrm{E}-01$ & $1.05 E+01$ & $7.50 E-02$ \\
\hline \multicolumn{5}{|c|}{ Average } & $6.60 \mathrm{E}-02$ & $8.69 \mathrm{E}-03$ & $4.99 E-04$ & $1.82 \mathrm{E}-03$ & $4.12 E-02$ & $2.17 \mathrm{E}+00$ & $1.51 \mathrm{E}-02$ \\
\hline \multicolumn{5}{|c|}{ std Der } & $7.64 \mathrm{E}-02$ & $9.39 \mathrm{E}-03$ & $1.38 E-03$ & $7.05 E-03$ & $4.64 \mathrm{E}-02$. & $2.65 E+00$ & 1. $90 \mathrm{E}-02$ \\
\hline
\end{tabular}

NOTE: CAP DATE is number of days from date canister capped to date canister sipped.

TOTAL BREAK is number of broken fuel elements when canister is decapped. 
Table A-2

Reduced Data Set - UNI-N-462 Sipping Data

\begin{tabular}{|c|c|c|c|c|c|c|c|c|c|c|c|}
\hline $\begin{array}{c}\text { CANISTER } \\
\text { No. } \\
\end{array}$ & BARREI & $\begin{array}{c}\text { KEY } \\
\# \\
\end{array}$ & $\begin{array}{c}\text { CAP } \\
\text { DATR }\end{array}$ & $\begin{array}{c}\text { TOTAL } \\
\text { BRRAKS }\end{array}$ & $\begin{array}{c}\text { Co137 } \\
\mathrm{CI}\end{array}$ & $\begin{array}{c}\mathrm{Cs137} \\
\mathrm{C} 1 \\
\end{array}$ & $\begin{array}{c}\text { Co60 } \\
\text { C1 }\end{array}$ & $\begin{array}{c}\mathrm{Mn} 54 \\
\mathrm{C} 1\end{array}$ & $\begin{array}{c}\text { Sr90 } \\
\text { CI }\end{array}$ & $\begin{array}{l}\text { Fuel } \\
\text { gims }\end{array}$ & $\begin{array}{c}F 18 s 110 \\
\text { gmo }\end{array}$ \\
\hline 1292 & $\mathbf{T}$ & 2201 & 513 & 1 & $3.10 \mathrm{E}-01$ & $2.80 \mathrm{E}-02$ & 0 & 0 & $1.90 \mathrm{E}-01$ & $1.05 \mathrm{E}+01$ & $7.50 \mathrm{E}-02$ \\
\hline 959 & $\mathrm{U}$ & 2852 & 464 & 3 & $1.89 \mathrm{E}-01$ & $3.40 \mathrm{E}-02$ & $2.10 \mathrm{E}-04$ & $2.00 \mathrm{E}-04$ & $2.40 \mathrm{E}-02$ & $6.43 E+00$ & $4.30 \mathrm{E}-02$ \\
\hline 1230 & $\mathrm{U}$ & 2127 & 519 & 1 & $1.30 \mathrm{E}-01$ & $9.70 \mathrm{E}-03$ & 0 & $1.20 \mathrm{E}-04$ & $8.80 \mathrm{E}-02$ & $5.22 \mathrm{E}+00$ & $4.00 \mathrm{E}-02$ \\
\hline 2550 & $\mathrm{~T}$ & 3016 & 251 & 1 & $8.40 \mathrm{E}-02$ & $1.80 \mathrm{E}-02$ & 0 & $3.20 \mathrm{E}-04$ & $4.66 \mathrm{E}-02$ & $2.22 \mathrm{E}+00$ & $1.40 \mathrm{E}-02$ \\
\hline 2670 & $\mathbf{T}$ & 2942 & 251 & 1 & $7.60 \mathrm{E}-02$ & $1.35 \mathrm{E}-02$ & $6.50 \mathrm{E}-04$ & $7.00 \mathrm{E}-04$ & $4.60 \mathrm{E}-02$ & $2.30 \mathrm{E}+00$ & $1.60 \mathrm{E}-02$ \\
\hline 1292 & 0 & 2201 & 513 & 1 & $6.20 \mathrm{E}-02$ & $6.20 \mathrm{E}-03$ & 0 & $1.40 \mathrm{E}-05$ & $3.60 \mathrm{E}-02$ & $1.85 \mathrm{E}+00$ & $1.20 \mathrm{E}-02$ \\
\hline 2670 & $\mathbf{U}$ & 2942 & 251 & 1 & $4.90 \mathrm{E}-02$ & $1.00 \mathrm{E}-02$ & $3.70 \mathrm{E}-04$ & $2.00 \mathrm{E}-04$ & $2.60 E-02$ & $1.20 \mathrm{E}+00$ & $7.20 E-03$ \\
\hline 1825 & $\mathrm{U}$ & 2480 & 498 & 1 & 4. $40 \mathrm{E}-02$ & $5.00 \mathrm{E}-03$ & $1.90 \mathrm{E}-04$ & $9.30 \mathrm{E}-05$ & $2.80 \mathrm{E}-02$ & $1.50 \mathrm{E}+00$ & $1.10 \mathrm{E}-02$ \\
\hline 1091 & $\mathbf{U}$ & 2201 & 510 & 2 & 3. $90 \mathrm{E}-02$ & $3.90 \mathrm{E}-03$ & $1.10 \mathrm{E}-04$ & $9.70 \mathrm{E}-05$ & $2.30 \mathrm{E}-02$ & $1.20 \mathrm{E}+00$ & $7.60 \mathrm{E}-03$ \\
\hline 1091 & $\mathbf{U}$ & 2201 & 512 & 2 & $3.80 \mathrm{E}-02$ & $3.10 \mathrm{E}-03$ & $4.50 \mathrm{E}-05$ & $4.90 E-05$ & $2.50 \mathrm{E}-02$ & $1.40 \mathrm{E}+00$ & $1.05 E-02$ \\
\hline 857 & $\mathbf{T}$ & 3015 & 469 & 1 & $3.41 \mathrm{E}-02$ & $6.23 \mathrm{E}-03$ & 0.00596 & 0.03007 & $4.20 \mathrm{E}-02$ & $1.33 \mathrm{E}+00$ & $9.40 \mathrm{E}-03$ \\
\hline 2283 & U & 3016 & 244 & 2 & $3.20 \mathrm{E}-02$ & $7.98 \mathrm{E}-03$ & $3.70 \mathrm{E}-04$ & $2.80 E-04$ & $1.50 \mathrm{E}-02$ & $6.90 \mathrm{E}-01$ & $3.50 \mathrm{E}-03$ \\
\hline 1035 & $\mathbf{T}$ & 2127 & 528 & 2 & $3.06 \mathrm{E}-02$ & $3.20 \mathrm{E}-03$ & $5.10 \mathrm{E}-05$ & $1.60 \mathrm{E}-04$ & $1.60 \mathrm{E}-02$ & $8.00 \mathrm{E}-01$ & $4.70 \mathrm{E}-03$ \\
\hline 1035 & $\mathbf{T}$ & 2127 & 530 & 2 & $3.00 \mathrm{E}-02$ & $2.40 \mathrm{E}-03$ & $5.90 \mathrm{E}-05$ & $6.40 \mathrm{E}-05$ & $1.09 \mathrm{E}-01$ & $1.07 \mathrm{E}+00$ & $7.80 \mathrm{E}-03$ \\
\hline 1728 & U & 2480 & 946 & $\mathrm{BF}$ & $2.90 \mathrm{E}-02$ & $3.20 \mathrm{E}-03$ & $9.50 \mathrm{E}-05$ & $1.00 \mathrm{E}-04$ & $1.90 \mathrm{E}-02$ & $1.02 \mathrm{E}+00$ & $7.50 \mathrm{E}-03$ \\
\hline \multicolumn{5}{|c|}{ Minimum } & $2.90 \mathrm{E}-02$ & $2.40 \mathrm{E}-03$ & $0.00 \mathrm{E}+00$ & $0.00 \mathrm{E}+00$ & $1.50 \mathrm{E}-02$ & $6.90 \mathrm{E}-01$ & $3.50 \mathrm{E}-03$ \\
\hline \multicolumn{5}{|c|}{ Maximum } & $3.10 \mathrm{E}-01$ & $3.40 \mathrm{E}-02$ & $5.96 \mathrm{E}-03$ & $3.01 \mathrm{E}-02$ & $1.90 \mathrm{E}-01$ & $1.05 \mathrm{E}+01$ & $7.50 \mathrm{E}-02$ \\
\hline \multicolumn{5}{|c|}{ Average } & $7.84 \mathrm{E}-02$ & $1.03 \mathrm{E}-02$ & $5.41 \mathrm{E}-04$ & $2.16 \mathrm{E}-03$ & $4.89 \mathrm{E}-02$ & $2.58 \mathrm{E}+00$ & $1.79 \mathrm{E}-02$ \\
\hline \multicolumn{5}{|c|}{ std Dov } & $7.80 \mathrm{E}-02$ & $9.52 \mathrm{E}-03$ & $1.51 \mathrm{E}-03$ & $7.72 \mathrm{E}-03$ & $4.72 \mathrm{E}-02$ & $2.73 \mathrm{E}+00$ & $1.97 \mathrm{E}-02$ \\
\hline \multicolumn{5}{|c|}{988} & $3.91-01$ & $4.84 E-02$ & $6.58 \mathrm{E}-03$ & $3.31 \mathrm{E}-02$ & $2.38 \mathrm{E}-01$ & $1.35 \mathrm{E}+01$ & $9.66 \mathrm{E}-02$ \\
\hline
\end{tabular}


WHC-SD-SNF-ES-006, REV. 0

\section{Table A-3}

Projected 1995 Cs 137 Levels in Fissile Material in KW Basin Canister Barrels

\begin{tabular}{|c|c|c|c|c|c|c|}
\hline & $\begin{array}{c}\text { C. } 137 \\
\text { In } 1983 \\
C 1\end{array}$ & $\begin{array}{l}\text { C. } 137 \\
\text { Inach Rate } \\
\text { C1/day }\end{array}$ & $\begin{array}{c}\text { Ce } 137 \\
\text { In } 1995 \\
C i\end{array}$ & $\begin{array}{c}\text { Fise110 } \\
\text { in } 1983 \\
\text { gme }\end{array}$ & $\begin{array}{l}\text { Fies1le } \\
\text { Ieach Rate } \\
\text { gme/day }\end{array}$ & $\begin{array}{c}\text { Fise1le } \\
\text { In } 1995 \\
\text { gins }\end{array}$ \\
\hline Average & $7.84 \mathrm{E}-02$ & $1.87 E-04$ & $6.96 \mathrm{E}-01$ & $1.79 \mathrm{E}-02$ & $4.07 E-05$ & $1.79 \mathrm{E}-05$ \\
\hline $\begin{array}{l}98 z \\
\text { Probability } \\
\text { Values }\end{array}$ & $3.91 \mathrm{E}-01$ & $8.42 E-04$ & $3.71 E+00$ & $9.60 \mathrm{E}-02$ & $1.98 E-04$ & $8.68 \mathrm{E}-01$ \\
\hline
\end{tabular}


WHC-SD-SNF-ES-006, REV. 0

Table A-4

KE Basin Visual Inspection Results

\begin{tabular}{|c|c|c|c|c|}
\hline \multirow[b]{2}{*}{$\begin{array}{l}\text { Number of Fuel } \\
\text { Elements with Leaks } \\
\text { and Breaks per Canister }\end{array}$} & \multicolumn{2}{|c|}{ Observed } & \multicolumn{2}{|c|}{ Poisson Distribution } \\
\hline & Fraction & Cumulative & Fraction & Cumulative \\
\hline 0 & 0.7028 & 0.7028 & 0.657 & 0.675 \\
\hline 1 & 0.2123 & 0.9151 & 0.276 & 0.933 \\
\hline 2 & 0.05848 & 0.97358 & 0.058 & 0.991 \\
\hline 3 & $1.923 \mathrm{E}-2$ & 0.9928 & 0.008 & 0.999 \\
\hline$\overline{4}$ & $5.408 \mathrm{E}-3$ & $>0.99$ & $8.5 \mathrm{E}-4$ & $>0.99$ \\
\hline 5 & $1.402 \mathrm{E}-3$ & $>0.99$ & $5.0 \mathrm{E}-6$ & $>0.99$ \\
\hline 6 & $2.003 E-4$ & $>0.99$ & $5.0 \mathrm{E}-6$ & $>0.99$ \\
\hline 7 & $2.003 \mathrm{E}-4$ & $>0.99$ & $3.0 \mathrm{E}-7$ & $>0.99$ \\
\hline
\end{tabular}


WHC-SD-SNF-ES-006, REV. 0

Table A-5

KE Canister Barrel Leach Rate Probabilities*

\begin{tabular}{|l|l|l|l|l|l|}
\hline Percent Badly Failed Fuel & \multicolumn{3}{|c|}{6} & \multicolumn{2}{c|}{3} \\
\hline Leach Rate Per Fuel Element & \multicolumn{3}{|c|}{$1300 \mu \mathrm{Ci} / \mathrm{day}$} \\
\hline $\begin{array}{l}\text { Number of Failed Fuel } \\
\text { Elements in Barrel }\end{array}$ & $\begin{array}{c}\text { Probability of } \\
\text { Occurrence }\end{array}$ & $\begin{array}{c}\text { Sum of } \\
\text { Probabilities } \\
\text { Leach Rate } \\
\mu \mathrm{Ci} / \text { day }\end{array}$ & $\begin{array}{c}\text { Probability of } \\
\text { Occurrence }\end{array}$ & $\begin{array}{c}\text { Adjusted } \\
\text { Sum of } \\
\text { Probabilities }\end{array}$ & $\begin{array}{c}\text { Leach Rate } \\
\mu \mathrm{Ci} / \text { day }\end{array}$ \\
\hline 0 & 0.6570 & 0.6570 & 0 & 0.8106 & 0.8106 \\
\hline 1 & 0.2760 & 0.9330 & 1300 & 0.1702 & 0.9808 \\
\hline 2 & 0.0580 & 0.9910 & 2600 & 0.0179 & 0.9987 \\
\hline 3 & $8.113 \mathrm{E}-03$ & $>0.99$ & & 0.0013 & $>0.99$ \\
\hline 4 & $8.519 \mathrm{E}-04$ & $>0.99$ & & $6.568 \mathrm{E}-05$ & $>0.99$ \\
\hline 5 & $7.156 \mathrm{E}-05$ & $>0.99$ & & $2.759 \mathrm{E}-06$ & $>0.99$ \\
\hline 6 & $5.009 \mathrm{E}-06$ & $>0.99$ & & $9.656 \mathrm{E}-08$ & $>0.99$ \\
\hline 7 & $3.005 \mathrm{E}-07$ & $>0.99$ & & $2.897 \mathrm{E}-09$ & $>0.99$ \\
\hline
\end{tabular}

\begin{tabular}{|l|l|l|l|l|l|l|}
\hline Percent Badly Failed Fuel & \multicolumn{3}{|c|}{6} & \multicolumn{3}{c|}{12} \\
\hline Leach Rate Per Fuel Element & \multicolumn{3}{|c|}{$1300 \mu \mathrm{Ci} /$ day } \\
\hline $\begin{array}{l}\text { Number of Failed Fuel } \\
\text { Elements in Barrel }\end{array}$ & $\begin{array}{c}\text { Probability of } \\
\text { Occurrence }\end{array}$ & $\begin{array}{c}\text { Sum of } \\
\text { Probabilities }\end{array}$ & $\begin{array}{c}\text { Barrel } \\
\text { Leach Rate } \\
\mu \mathrm{Ci} / \text { day }\end{array}$ & $\begin{array}{l}\text { Probability of } \\
\text { Occurrence }\end{array}$ & $\begin{array}{c}\text { Adjusted } \\
\text { Sum of } \\
\text { Probabilities }\end{array}$ & $\begin{array}{c}\text { Barrel } \\
\text { Leach Rate } \\
\mu \mathrm{Ci} / \text { day }\end{array}$ \\
\hline 0 & 0.6570 & 0.6570 & 0 & 0.4317 & 0.4317 & 0 \\
\hline 1 & 0.2760 & 0.9330 & 1300 & 0.3626 & 0.7943 & 650 \\
\hline 2 & 0.0580 & 0.9910 & 2600 & 0.1523 & 0.9467 & 1300 \\
\hline 3 & $8.113 \mathrm{E}-03$ & $>0.99$ & & 0.0426 & 0.9893 & 1950 \\
\hline 4 & $8.519 \mathrm{E}-04$ & $>0.99$ & & $8.956 \mathrm{E}-03$ & $>0.99$ & \\
\hline 5 & $7.156 \mathrm{E}-05$ & $>0.99$ & & $1.505 \mathrm{E}-03$ & $>0.99$ & \\
\hline 6 & $5.009 \mathrm{E}-06$ & $>0.99$ & & $2.106 \mathrm{E}-04$ & $>0.99$ & \\
\hline 7 & $3.005 \mathrm{E}-07$ & $>0.99$ & & $2.528 \mathrm{E}-05$ & $>0.99$ & \\
\hline
\end{tabular}

*Based on KE Basin Leach Rate of 4 Ci/day (See Figure A-1) 

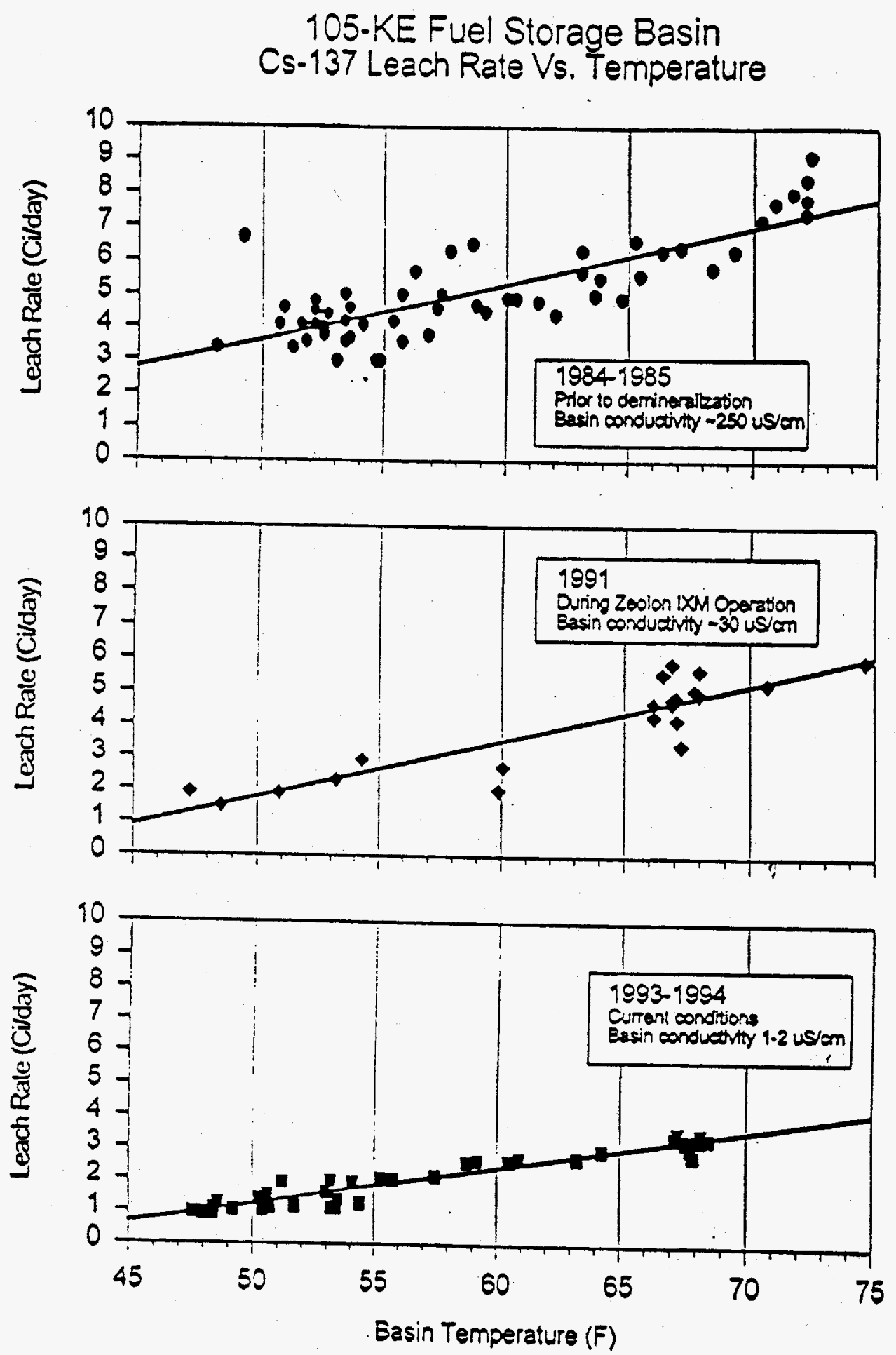

Figure A-1 
WHC-SD-SNF-ES-006, REV. 0

Appendix A

Attachments

Appendix A

Page 12 of 12 
G. L. Smith

Fiom.

R. J. Nicklas

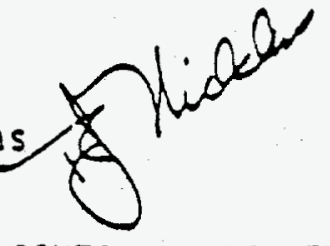

Oate February 16,1983

1. CHARCOAL PROGRAM -- Finished the semi-annual in-place testing of the I $17-N$ charcoal filters friday. The results of the in-place tests are as follows:

Efficiency

$\begin{array}{ll}A-C e l l & 99.82 \% \\ B-C e l l & 99.48 \% \\ C-C e l l & 99.30 \% \\ 0-C e l l & 99.99 \%\end{array}$

2. KE CAIISTER CONTAMINATION LEVEL REPORT -- Comments have been received and are being incorporated into the text. The final report should be routing for signatures by February 15.

3. FUEL SIPPING -- Counting of sipping samples has produced some very encouraging results. Radioisotope levels are much lower than expected, averaging $0.066 \mathrm{Ci}$ Cs-137 per canister barrel (0.3l Ci maximum). This may increase our options for location of canister decapping and fuel reencapsulation activities.

4. G. A. IRRAOIATION -- Discharged a batch of General Atomics Li-A samples from traverse channel 5. At the time of discharge, a portable Triton meter indicated Tritium gas was being emitted excessively from the samples, but further investigation and evaluation suggested the high reading to be caused by the garma radiation field oscurring at the time of discharge.

RJN:dmn

CE: CSHTT (12)

OH Johnson

AP Larrick

SL Paris

RJN-LG/File 
11. FUEL SIPPER ACTIVITIES - D. B. Bechtold

Worked on getting the sipper samples counted, the results computed, and situation analyzed for a meeting on Friday. The executive summary: there does not appear to be much in the way of fuel corrosion. The details:

1) We can repeat Cs-137 counts on duplicate samples to \pm 10 percent.

2) None of the eighteen assorted samples are as "cool" as typical $N$ Basin surface water. Of course these cans were pacxaged on the bottom of $N$ Basin where radionuclide concentrations are expected to be higher.

3) Only three canisters were completely sampled (both barrels) and we can only half-believe the extent of breakage claimed to be in them by Fuel Processing; however there appears to be a positive correlation with extent of breakage and with time. This encourages our notions that we can understand what is going on.

4) The averages for eighteen barrels in releasable amounts were:

- Cs-137-0.066 Curies

$*$

- Cs-134 - 0.0087 Curies

- Co-60 - $6.9 \times 10^{-4}$ Curies

- Mn-54 - $1.9 \times 10^{-3}$ Curies

with wild variation. The worst case: $0.31 \mathrm{Ci}$ of Cs-137, could have accounted for one-seventh of the current $\mathrm{KW}$ Basin load had it leaked this amount over its capping time. There are indications that perhaps as few as one canister may at one time have leaked twelve times as much as this can's theóretical leak rate. Therefore, our measured worst case might possibly be only one-twelfth as bad as a real worst case.

5) Having si pled fuel "known" to contain broken pieces should hule biased us to find the worst cases. Therefore it appears that the fuel corrosion problem is minimal.

6) The calculated releases of uranium, fissile, and $5 r-90$ have to be in error because the calculated exposures exceeded the possible. They varied from 6,000 to $10,000 \mathrm{MHO} / \mathrm{T}$, based on the four-year decay ratio Cs-134/Cs-137. This has to reflect a problem with the assumptions of even leaching of fission products and/or the validity of RIBD. With this disclaimer we averaged, by calculation:

- Sr-90. $\quad 0.87$ Curies

- Uranium. 2.2 grams

- Fissile - 0.15 grams. 


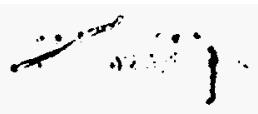

\section{URE NUELERR INDUSTRRES}

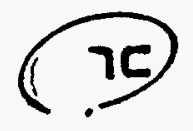

A UNC RESOURCES COMPanY

PO BOx $490^{\circ}$

Ricliland .Wisshingion 99352

Telephone 508/376.7411

Memorandum

To:

J. K. Ostic

Dale. April 20, 1983

From.

W. K. Kratzer

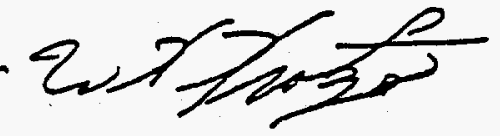

Subject:

EFFECT OF DECAPPING MARK II CANISTERSAT EACH OF THE

BASINS WITH AND WITHOUT AUXILIARY ION EXCHANGE MODULES

In response to your request for an analysis of the effect of Mark II canister decapping at each of the basins on radionuclide concentration in the basins and dose rates to be expected, Table 1 gives the expected Cs-137 concentrations and Table 2 gives the expected dose. rates from the water in each of the areas of concern. A bas in flow arrangement as shown in Figure 1 and Figure 2 is assumed for the $K$ East and $K$ West basins.

With auxiliary ion exchange modules (IXM) taking 95 percent of the released soluble radionuclides directly from the opened canisters, we can expect an increase of 2 or $3 \mathrm{mR} / \mathrm{hr}$ in either $K$ East pickup chutes (PUC) or the $K$ West loadout pit (LOP) over the dose rate readings without decapping. The $K$ East main bas in would increase. about $2 \mathrm{mR} / \mathrm{hr}$; the $K$ West ma in basin would be unaffected, except: that the already low $\mathrm{Cs}_{S}-137$ concentration would be reduced even further.

Decapping in any basin without effective IXM cleanup would give intolerably high dose rates at the decapping location.

Calcuations and assumptions are given in the appendix.

$W K K: d m n$

CC: GL Erickson

VL Hoefer

AP Larrick

PJ Lee

RJ Nicklas

SL Paris

GL Smith

WKK-LB/File 


\section{APPENDIX B \\ CANISTER CHARACTERISTICS AND IMPACT ON GAS AND LIQUID SAMPLING}

KW MKII canisters consist of two fully capped barrels, each containing seven $\mathrm{N}$ Reactor fuel assemblies. The canister assembly is shown in Drawing H-1-46215, which is included in this Appendix as Figure B-1. Each barrel has a gasketed cap and two vent valves, one located in the center of the barrel cap, the other located on the periphery of the cap. The center vent valve is provided with a $21 / 2$ inch tube that extends down through the cap into the interior of the barrel. This extension is used to establish a $21 / 2$ inch gas space in the top part of the barrel when the barrel was initially loaded and capped. Figure B-1 shows that the storage barrel gas space is connected to a gas trap by a small unvalved vent line. Inside of the gas trap is a vertical line that vents excess gas into the basin from the top of the gas trap.

The two vent valves provide the means to sample the barrel gas space before the barrel is uncapped for fuel sampling; the amount of $\mathrm{Kr} 85$ activity in the gas sample is an indication of the quantity of fission products that have leached out of the fuel. Venting prior to uncapping can also be used to reduce the release of fission gases into the basin air space and further release into the environment via the ventilation system. Also, as the barrel vents, the gas space will fill with water from the basin water. If there is uranium hydride in the barrel, venting prior to uncapping will control the rate that hydrogen is generated and released into the basin.

\section{Canister Barrel Volumes}

Interpretation of the information obtained from gas sampling depends on the initial fuel content and the water and gas space volumes in the barrel and the changes in gas pressure and volumes that have taken place since the canisters were capped. The volumes of interest are: 


\section{Empty barrel volume, Ve}

According to drawing H-1-46215, the internal diameter of the barrels is 8.074 \pm 0.054 inches and the effective internal height of the barrel is 27 inches less $1 / 8$ inch thickness of the cover plate, and approximately 0.3 inches of the bottom plate, or $27.0-.125-0.3=26.575$ inches. Therefore:

$$
\mathrm{Ve}=(\pi / 4) \times D^{2} \times \mathrm{L}=(\pi / 4) \times(8.074)^{2} \times 26.575=1360 \mathrm{in}^{3}=22300 \mathrm{cc}
$$

This value is consistent with a value of $1380 \mathrm{in}^{3}$ reported by Conn which used a maximum barrel diameter of $8.074+0.54=8.128$ inches.

\section{Fuel Volume, Vf}

Per Weber, the fuel volume varies from 5400 to $10200 \mathrm{cc}$ depending on the size of fuel being stored. The largest fuel volume is associated with the longest fuel, 26.1 inches.

\section{Gas Space Volume, Vg}

The height of the gas space at the top of the barrel is $21 / 2$ inches, leaving a water space height of $26.875-2.5=24.375$ inches. Thus, the longest fuel element will protrude $26.1-24.375=1.725$ inches into the gas space. The largest gas space is the $21 / 2$ inch height without fuel protruding into the gas space, or

$$
\mathrm{Vg}=(\pi / 4) \times D^{2} \times \mathrm{L}=(\pi / 4) \times(8.074)^{2} \times 2.5=128 \mathrm{in}^{3}=2098 \mathrm{cc}
$$

The smallest gas space, associated with 26.1 inch fuel which protrudes into the gas space is 83.03 in $^{3}$ or $1330 \mathrm{cc}$ (Conn).

\section{Water Volume, Vw}

Using the above data, the volume of fuel and water below the gas space is calculated as:

$$
\mathrm{Vo}=(\pi / 4) \times \mathrm{D}^{2} \times \mathrm{L}=(\pi / 4) \times(8.074)^{2} \times 24.375=1248 \mathrm{in}^{3}=20,450 \mathrm{cc}
$$

The net water volume is smallest in barrels containing the longest fuel:

$$
V w=20450-10200 \times(24.375 / 26.1)=10975 c c
$$


The net water volume is largest in barrels containing the smallest fuel:

$$
V w=20450-5400=15,050 \mathrm{cc}
$$

\section{Gas Trap Volume}

The net gas trap volume to be $48.174 \mathrm{in}^{3}$ or $790 \mathrm{cc}$ for a gas trap length of 16.82 inches (Conn).

Even if there have been no leaks in the canister/gas trap system, there has been a significant change in the water and gas volume relationships in the barrels which were capped under hydrostatic head of $N$ Basin water then moved up to atmospheric pressure conditions when they were moved to KW Basin. The situation is as follows:

1. After the barrels were capped under approximately 16 feet of $N$ Basin water, the barrels were purged with nitrogen using the center vent valve until $\mathrm{N}_{2}$ gas vented from the top of the gas trap. This process created a $21 / 2$ inch high gas volume in the barrel and a $656 \mathrm{cc}$ gas volume in the gas trap, both at approximately $11 / 2$ atmospheres or 21 psia.

2. When the canisters were lifted out of $\mathrm{N}$ Basin for transport to $\mathrm{K}$ Basin, the gas trap and the barrel gas space vented to atmospheric pressure with the combined gas volume of the barrel and gas trap remaining at the original value.

3. When the canisters were lowered back into 16 feet of water in the KW basin, the gas trap was repressurized to approximately $11 / 2$ atmospheres. This had the effect of reducing the total gas volume to approximately two-thirds the initial combined gas trap and barrel gas volume. The reduction in total gas volume will occur in the gas trap which will partially fill with water. 
WHC-SD-NR-ANAL-009 reports calculations of water levels in the gas traps for the canisters in their present KW Basin locations; the bottom of the canisters located $161 / 2$ feet below basin water level. The water levels are dependent on the type of fuel in the canister, short fuel or longer fuel protruding into the barrel air space. The results are summarized in Table B-1. The table also shows $\mathrm{Kr} 85$ gas activity assuming that $0.30^{1} \mathrm{Ci}$ of $\mathrm{Kr} 85$ has leached from the fuel into the gas volume. Table B-1 shows less than 2 to 1 variation in activity depending on the type of fuel being stored.

${ }^{1}$ This value assumes that all of the $\mathrm{Kr} 85$ stays in the canister gas space and is quickly released rather than slowly vented to the environment. Additionally, it does not account for dilution by hydrogen generated during the corrosion process. 
Table B-1

KW Canister Gas Trap Water Level and Gas Volume/Activity

\begin{tabular}{|c|c|c|c|c|c|}
\hline \multicolumn{4}{|c|}{ Data from WHC-SD-NR-ANAL-009 } & \multicolumn{2}{|c|}{ Additional Calculations } \\
\hline Fuel Type & $\begin{array}{c}\text { Initial Total } \\
\text { Gas Volume } \\
\text { (Note 2) }\end{array}$ & $\begin{array}{c}\text { Gas Trap } \\
\text { Water Level } \\
\text { (Note 3) }\end{array}$ & $\begin{array}{c}\text { Final Total } \\
\text { Gas Volume } \\
\text { (Note } 4 \text { ) }\end{array}$ & $\begin{array}{c}\text { Final Total } \\
\text { Gas Volume } \\
\text { (Note 4) }\end{array}$ & $\begin{array}{c}\text { Gas Activity } \\
\text { (Note 5) }\end{array}$ \\
\hline $26^{\prime \prime}$ MK IV Fuel & $129.92 \mathrm{in}^{3}$ & 11.84 inches & $\begin{array}{l}95.1 \text { in }^{3} \\
@ 21.19 \text { psia }\end{array}$ & $1558 \mathrm{cc}$ or $\mathrm{ml}$ & $172 \mu \mathrm{Ci} / \mathrm{ml}$ \\
\hline $24.5^{\prime \prime}$ MK IV Fuel & $166.87 \mathrm{in}^{3}$ & 14.98 inches & $\begin{array}{l}122.82 \text { in }^{3} \\
@ 21.08 \text { psia }\end{array}$ & $2013 \mathrm{cc}$ or $\mathrm{ml}$ & $134.1 \mu \mathrm{Ci} / \mathrm{ml}$ \\
\hline Fuel $<24^{\prime \prime}$ & $177.9 \mathrm{in}^{3}$ & 15.91 inches & $\begin{array}{l}131.11 \text { in }^{3} \\
\text { (a) 21.05 psia }\end{array}$ & $2149 \mathrm{cc}$ or $\mathrm{ml}$ & $125.8 \mu \mathrm{Ci} / \mathrm{ml}$ \\
\hline $\begin{array}{l}\text { Special Case } \\
\text { (Note 1) }\end{array}$ & $69.91 \mathrm{in}^{3}$ & 6.54 inches & $\begin{array}{l}50.68 \text { in }^{3} \\
\text { @ } 21.39 \text { psia }\end{array}$ & $830 \mathrm{cc}$ or $\mathrm{ml}$ & $320 \mu \mathrm{Ci} / \mathrm{ml}$ \\
\hline
\end{tabular}

NOTE 1: Assumes barrel water level is at bottom of connecting tube to gas trap due to incomplete purging of barrel during capping.

NOTE 2: Initial total gas volume is barrel gas space plus gas trap.

NOTE 3: The water level in gas trap increases when canister is lowered into the $\mathrm{KW}$ Basin.

NOTE 4: After canister is lowered into KW Basin.

NOTE 5: Assuming $0.387 \mathrm{Ci}$ of $\mathrm{Kr} .85$ in gas when counted at atmospheric pressure. 
Table B-1 is based on several assumptions:

1. The gas trap, the barrel lid closure, and the peripheral vent valve have not leaked to any significant extent since encapsulation.

If there has been leakage, the gas trap water level will be higher than shown in Table B-1. If gas trap water level exceeds 16.5 inches (16.82 inches less the 0.32 inch projection of the vent tube into the gas trap), further barrel lid or vent valve leakage will cause water to draw into the barrel via the vent line connection to the gas trap. There are several possible conditions depending on the source of the gas leakage:

- If the peripheral valve leaks, it is possible that all the barrel gas space has vented during the storage period and all of the barrel gas has been replaced with basin water. In this case, there will be no gas to sample when the valve is opened for gas sampling prior to uncapping the barrel for fuel sampling.

- If the barrel lid closure leaks, it is possible that nearly all the barrel gas space and gas trap has vented and been replaced with basin water. In this case, the equilibrium barrel water level will rise to the elevation of the bottom of the outside of the lid and the lid will stop leaking. The resulting gap between the barrel water level and the inside surface of the lid will be approximately $1 / 8$ inch, resulting in a barrel gas volume of approximately $2 \mathrm{in}^{3}$ or approximately $2 \%$ of the volumes shown in Table B-1. The net effect is that activity levels in the gas sample could be much higher than in a non-leaking barrel. On the other hand, the total amount of gas that can be captured before it rises into the basin proper is correspondingly smaller.

- If the gas trap leaks, it will be because of a structural defect such as a cracked weld at an elevation above normal water level in the gas trap. In this case, the gas trap gas will vent out the defect and water level in the gas trap will rise until it submerges the defect. Table B-1 shows that water level in a non-leaking gas trap will be a significant fraction of the total gas trap height. Thus, the effect of a gas trap leak on total gas volume available to dilute fission gas concentrations is not significant compared to the effect of fuel length. 
WHC-SD-NR-ER-094 reports that 23, or 11\%, out of 210 ultrasonic measurements of gas trap water levels indicated water levels greater than 15.9 inches, the maximum value shown in Table B-1, indicating gas leakage has taken place in these canisters.

2. Gas has been generated in the barrel that expands the total gas volume by displacing water in the gas trap.

The initial content of the gas space and gas trap is nitrogen, $\mathrm{N}_{2}$, used to purge the barrels. The major source of additional gas is hydrogen generated by corrosion of uranium from the process $\mathrm{U}+2 \mathrm{H}_{2} \mathrm{O} \rightarrow \mathrm{UO}_{2}+2 \mathrm{H}_{2}$. The volume of hydrogen generated from corrosion of uranium can be estimated using the following data and assuming that leaching of Cs 137 is proportional to the amount of uranium corrosion:

Weight of uranium in Mark II fuel element (inner and outer)

Weight of seven Mark IV elements in a barrel $=7 \times 50$

Molecular weight of uranium

Molecular weight of water

Molecular weight of hydrogen

Specific volume of $\mathrm{H}_{2}$ at $0^{\circ} \mathrm{C}$ and $1 \mathrm{~atm}$

Specific volume of $\mathrm{H}_{2}$ at $28^{\circ} \mathrm{C}$ and $1.5 \mathrm{~atm}$

Total Cs 137 inventory in barrel (Section A-1)

Amount of leached Cs 137 in barrel (Section A-3)
$50 \mathrm{lbs}$

$350 \mathrm{lbs}$

238

18

2

$178.6 \mathrm{ft}^{3} / \mathrm{lb}$

$129.9 \mathrm{ft}^{3} / \mathrm{lb}$

$1927 \mathrm{Ci}$

$3.71 \mathrm{Ci}$

The amount of uranium corroded using this data will be approximately (3.71 Ci Cs 137)/(1927 Ci Cs 137) $=0.1925 \%$ of $350 \mathrm{lbs}$ or $0.68 \mathrm{lbs}$. This amount of corrosion will generate approximately $0.68 \times 2 \times 2 / 238=0.0113 \mathrm{lb}$ of $\mathrm{H}_{2}$. This amount of hydrogen is $1.46 \mathrm{ft}^{3}$ at 1.5 atmospheres. This volume is well in excess of the combined capacity of the gas trap and the gas space in the barrel $(790 \mathrm{cc}+2098 \mathrm{cc}=$ $2888 \mathrm{cc}$ or $\left.0.1 \mathrm{ft}^{3}\right)$. However, there are several processes competing for the hydrogen that is generated by corrosion:

(1) Most of the hydrogen could react with the uranium to form uranium hydride (This is considered to be highly unlikely). In this case, there may be a change in gas trap water level and total barrel and gas trap gas volume but the changes will not be great compared to the initial gas volume. The sample $\mathrm{Kr} 85$ gas activity relationship of Table B-1 will be applicable if most of the hydrogen reacts to form hydride. 
(2) The hydrogen could diffuse out of the barrel and gas trap through seemingly tight openings such as the barrel lid seal and vent gases or micro cracks in welds. Hydrogen has a propensity to leak through tight openings, much more than other gases which are heavier.

(3) Significant uranium hydride formation or hydrogen diffusion does not occur. In this case, the remaining hydrogen will displace the water in the gas trap until the amount of hydrogen exceeds the initial volumetric capacity of the gas trap. Additional hydrogen generated will then be released to atmosphere via the gas trap vent. The vented hydrogen will also purge and reduce the amount of nitrogen and fission gas in the barrel and gas trap. This will result in lower gas sample activity and a low estimate of fission product that may have leached into the barrel water. However, the gas sample $\mathrm{N}_{2}$ content will be low and the $\mathrm{H}_{2}$ will be high, an indication that corrosion and leaching of fission product is greater than indicated by the $\mathrm{Kr} 85$ activity level in the gas sample.

The fraction of hydrogen that diffuses into the basin water is uncertain and not predicable. The amount of hydride formation is also uncertain. There is a theory that after a small amount of hydride is formed, the formation process comes to equilibrium; some hydride continues to form but an equal amount returns to metallic uranium and molecular hydrogen.

In all likelihood, some of the hydrogen generated by corrosion will neither form hydride or diffuse, but will vent from the gas trap if the amount of hydrogen is in excess of that necessary to displace any water remaining in the gas trap. In this case, the amount of $\mathrm{Kr} 85$ will be reduced since some of it and $\mathrm{N}_{2}$ will vent from the gas trap with the hydrogen.

The analysis in Section 3.4 .3 shows that the $98 \%$ probability canister barrel $\mathrm{H} 3$ and $\mathrm{Kr} 85$ activity levels, such as described in Table 3-2 and Appendix $\mathrm{A}$ are not an occupational problem. Nevertheless, the canister barrel vent valves can be used to vent the barrel gas space before uncapping provides a means to control the release of fission gas and hydrogen that may form when any uranium hydride existing in the capped barrel reacts with water added to the barrel. Also, sampling of the vented gases for $\mathrm{Kr} 85$, as well as $\mathrm{N}_{2}$ and $\mathrm{H}_{2}$, is a means to estimate the amount of fission product that has leached into the barrel's water and will be released into the loadout pit water when the barrel is uncapped. If there has been hydrogen generated while the fuel has been stored in the Mark II canisters, the $\mathrm{Kr} 85$ activity level will most likely be diluted by the hydrogen and will be less than that predicted without taking into account the effects of hydrogen dilution. 

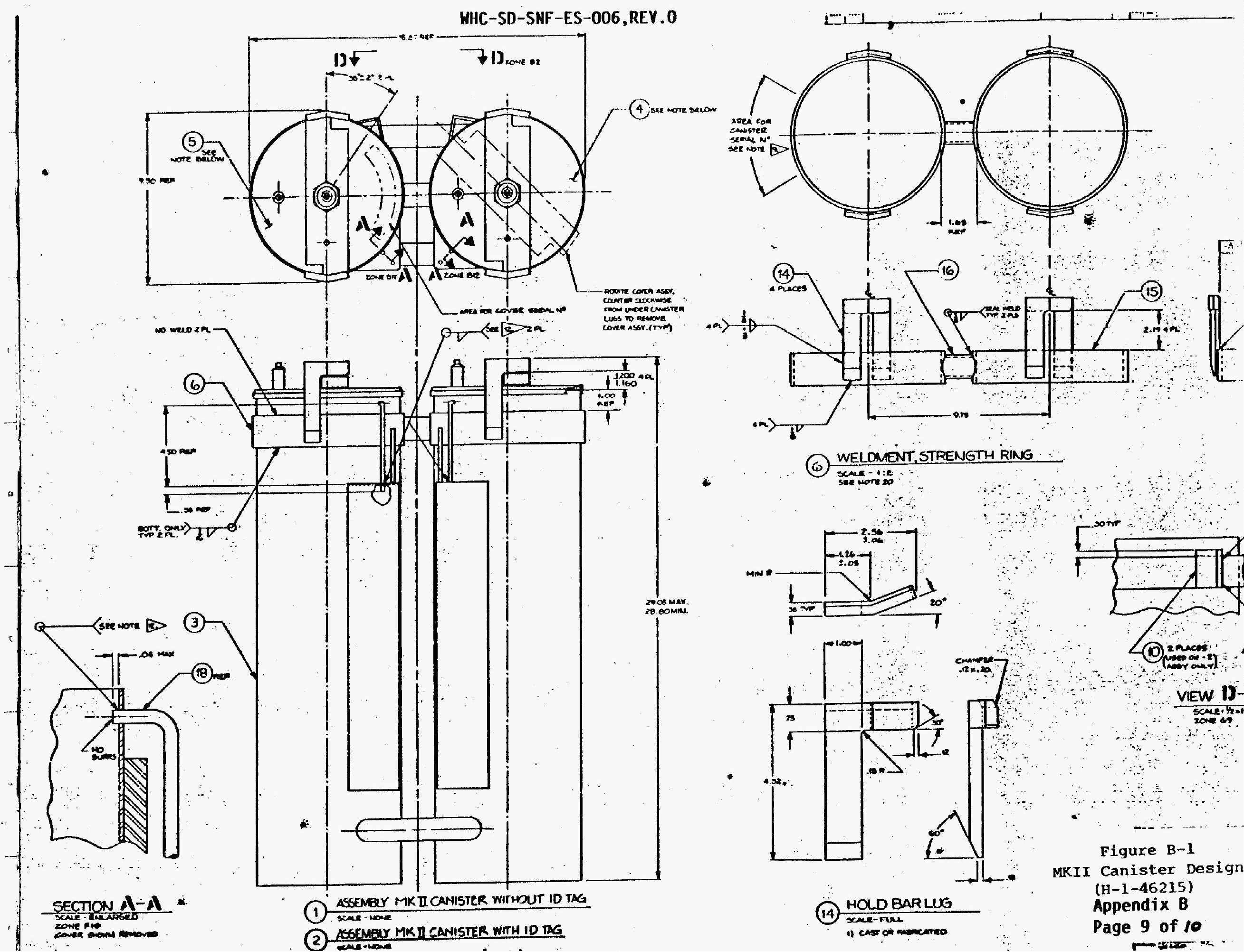

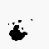

(6) WELOMENT STRENGTH RING
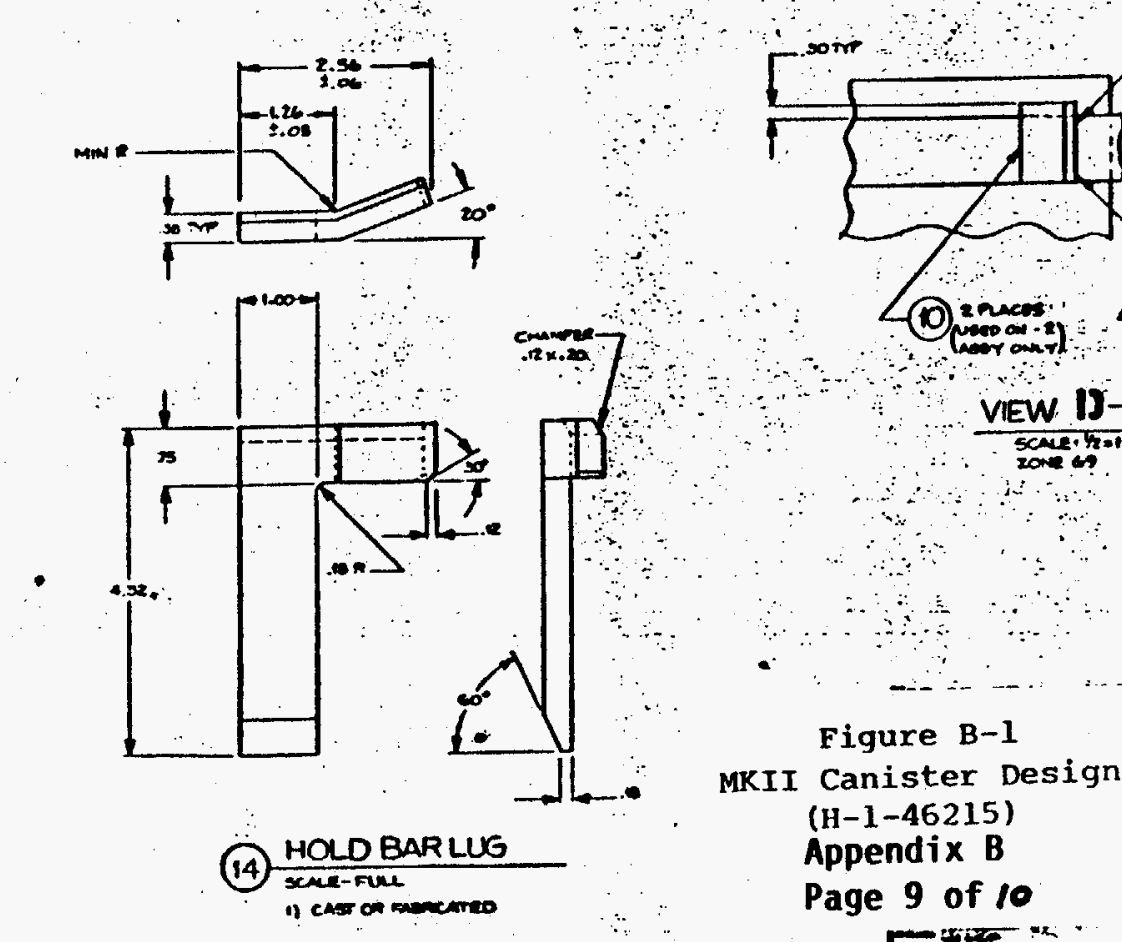

Figure $B-1$

MKII Canister Design (H-1-46215)

Page 9 of 10 - 
Pet- Owqs: $\begin{aligned} H-1-46215,5 h T, \text { Thry } \\ H-1-434+9\end{aligned}$

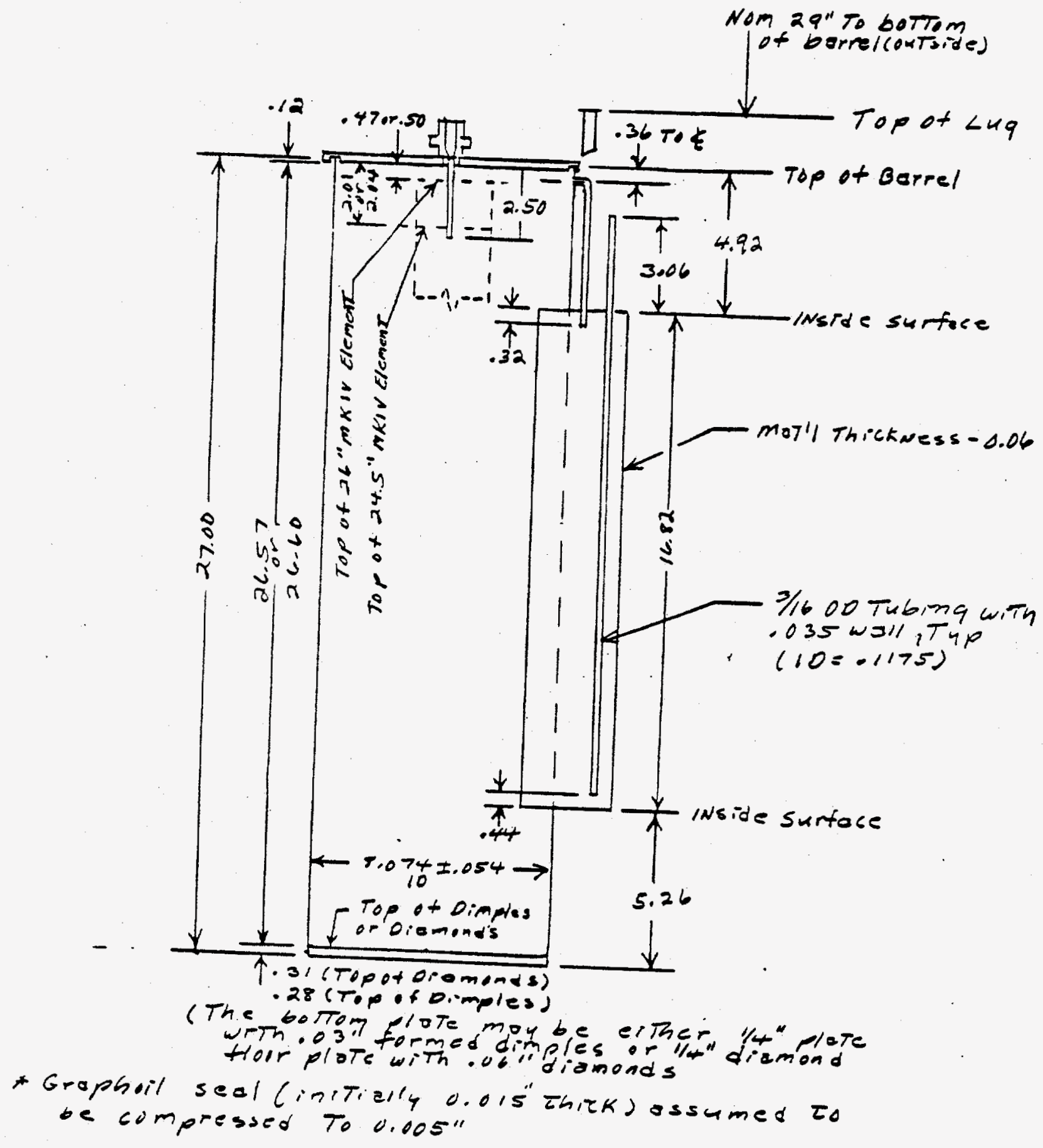

Figure B-2 


\section{APPENDIX C \\ ESTIMATED DOSE RATE ABOVE A WATER POOL FROM CS 137 IN THE POOL}

Assume that there is Cs 137 uniformly dissolved in a fuel pool, which is $10^{\prime} \times 10^{\prime} \times$ $16^{\prime}$ deep. The concentration of Cs 137 is $100 \mu \mathrm{c} /$ liter. Cs 137 emits a $661.70 \mathrm{Kev}$ gamma. It is desired to calculate the dose rate at the pool surface from the Cs 137.

The unshielded surface flux, $S_{A^{\prime}}$ is assumed to be from an infinite plane surface, $16^{\prime}$ deep:

$$
S_{A}=\frac{S_{v} \cdot h}{2}=\frac{100 \frac{\mu c}{l} \times \frac{1}{100} \frac{l}{\mathrm{~cm}^{3}} \times 488 \mathrm{~cm}}{2}=244 \frac{\mu c}{\mathrm{~cm}^{2}}
$$

Shielding effects: The surface flux, $S_{N}$ from the top 2 feet of water of the pool:

$$
S_{A}=244 \frac{\mu c}{c^{2}} \times \frac{2}{16}=30.5 \frac{\mu c}{\mathrm{~cm}^{2}}
$$

Evaluating $S_{A}$ to estimate self-shielding effect of the water, use the rule of thumb that $1 \mathrm{Mev}$ photons are reduced by a factor of 10 after traveling through 2 feet of water (See Figure C-1). 
Shielding Effect for Uniformly

Distributed Source in Water

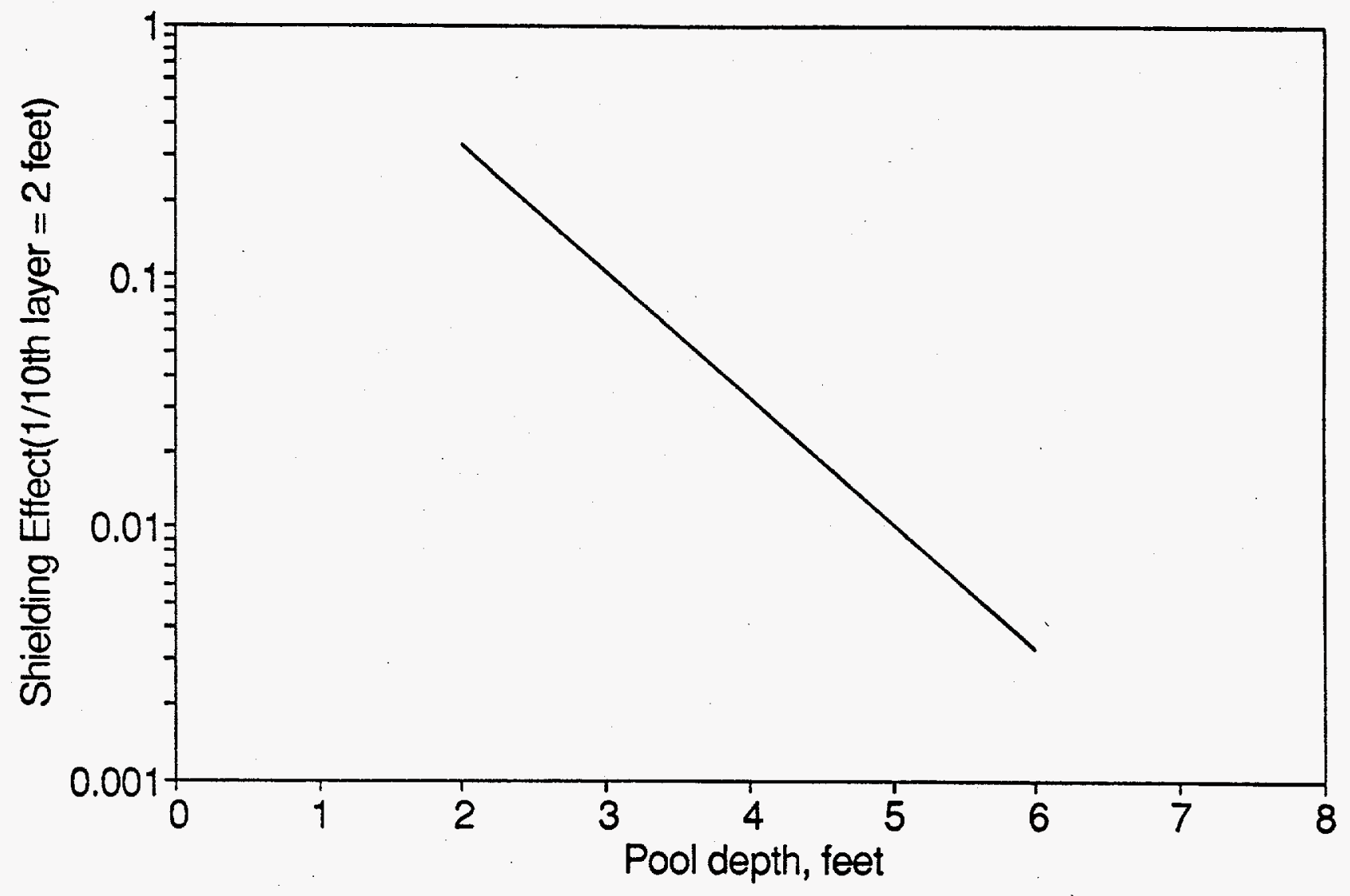

Figure C-1 
Therefore, estimating the water shielding effect, $S_{A^{\prime}}$ from water layer 0 to 2 feet deep:

$$
S_{A_{0}}^{2}=\frac{1}{3} S_{A}\left(0-2^{\prime}\right)
$$

Similarly, in the water layer 2 feet to 4 feet deep:

$$
S_{A_{2}}^{4}=\frac{1}{30} S_{A}\left(2^{\prime}-4^{\prime}\right)
$$

And for 4 feet to 6 feet deep:

$$
S_{A_{4}}^{6}=\frac{1}{300} S_{A}\left(4^{\prime}-6^{\prime}\right)
$$

Remember that

$$
\begin{aligned}
& S_{A}\left(0^{\prime}-2^{\prime}\right)=S_{A}\left(2^{\prime}-4^{\prime}\right)=S_{A}\left(4^{\prime}-6^{\prime}\right)=\frac{244}{\left(\frac{16^{\prime}}{2^{\prime}}\right)}=30.5 \frac{\mu c}{\mathrm{~cm}^{2}} \\
& \therefore \phi 0^{\prime}-16^{\prime}=S_{A_{0}}{ }^{2}+S_{A_{2}}{ }^{4}+S_{A_{4}}{ }^{6}+\cdots \\
& =S_{A_{2}}{ }^{0}\left(\frac{1}{3}+\frac{1}{30}+\frac{1}{300} \cdots\right) \\
& =30.5 \frac{\mu c}{\mathrm{~cm}^{2}}\left(\frac{1}{3}+\frac{1}{30}+\frac{1}{300} \cdots\right) \\
& =11.25 \frac{\mu c}{\mathrm{~cm}^{2}}
\end{aligned}
$$

\section{Conversion Factors:}

From Figure 2.1 of Rockwell:

1 photon $/ \mathrm{sec}$ at $0.661 \mathrm{Mev}$

and 1 curie

$1 \mu$ curie
$=1.0 \times 10^{-7} \mathrm{r} / \mathrm{hr}$

$$
=1.0 \times 10^{-4} \mathrm{mr} / \mathrm{hr}
$$

$=3.7 \times 10^{10}$ photons $/ \mathrm{sec}$

$=3.7 \times 10^{4}$ photons $/ \mathrm{sec}$ 


$$
\begin{aligned}
\text { Dose Rate } & =\left[11.25 \frac{\mu c}{\mathrm{~cm}^{2}}\right] \times\left[3.7 \times 10^{4} \frac{\text { photons }}{\mathrm{sec}} / \mu c\right] x\left[10^{-4} \frac{\mathrm{mr} / \mathrm{hr}}{\text { photons } / \mathrm{sec}}\right] \\
& =42 \frac{\mathrm{mr}}{\mathrm{cm}^{2}-\mathrm{hr}}
\end{aligned}
$$

This estimate is probably high due to several of the assumptions:

1. Use of 2 feet water for 1/10 layer factor. It could be as low a 1 foot. If so, then estimate could be high by a factor of $1 / 10$.

2. Assumption of infinite slab source. Radiation from the four edges of pool would contribute less than estimation method allows. It could be lower by a factor of 4 .

Using a $1 / 10$ layer value of $1^{\prime}$ rather than $2^{\prime}$ for water shielding and a factor of 4 for conservatism in the infinite plane assumption results in:

$$
\text { Dose Rate }=\left[42 \frac{\mathrm{mr}}{\mathrm{cm}^{2}-\mathrm{hr}}\right] x\left[\frac{1}{2 \times 4}\right]=5.2 \frac{\mathrm{mr}}{\mathrm{cm}^{2}-\mathrm{hr}} \quad \text { or } \sim 5 \mathrm{mr} / \mathrm{hr}
$$

